\title{
The Neurotrophin-Inducible Gene Vgf Regulates Hippocampal Function and Behavior through a Brain- Derived Neurotrophic Factor-Dependent Mechanism
}

\author{
Ozlem Bozdagi, ${ }^{1}$ Erin Rich, ${ }^{1}$ Sophie Tronel, ${ }^{1}$ Masato Sadahiro, ${ }^{1}$ Kamara Patterson, ${ }^{1}$ Matthew L. Shapiro, ${ }^{1,2}$ \\ Cristina M. Alberini, ${ }^{1}$ George W. Huntley, ${ }^{1}$ and Stephen R. J. Salton ${ }^{1,2}$ \\ Departments of ${ }^{1}$ Neuroscience and ${ }^{2}$ Geriatrics, Mount Sinai School of Medicine, New York, New York 10029
}

\begin{abstract}
VGF is a neurotrophin-inducible, activity-regulated gene product that is expressed in CNS and PNS neurons, in which it is processed into peptides and secreted. VGF synthesis is stimulated by BDNF, a critical regulator of hippocampal development and function, and two VGF C-terminal peptides increase synaptic activity in cultured hippocampal neurons. To assess VGF function in the hippocampus, we tested heterozygous and homozygous VGF knock-out mice in two different learning tasks, assessed long-term potentiation (LTP) and depression (LTD) in hippocampal slices from VGF mutant mice, and investigated how VGF C-terminal peptides modulate synaptic plasticity. Treatment of rat hippocampal slices with the VGF-derived peptide TLQP62 resulted in transient potentiation through a mechanism that was selectively blocked by the BDNF scavenger TrkB-Fc, the Trk tyrosine kinase inhibitor K252a (100 nM), and tPA STOP, an inhibitor of tissue plasminogen activator (tPA), an enzyme involved in pro-BDNF cleavage to BDNF, but was not blocked by the NMDA receptor antagonist APV, anti-p $75^{\mathrm{NTR}}$ function-blocking antiserum, or previous tetanic stimulation. Although LTP was normal in slices from VGF knock-out mice, LTD could not be induced, and VGF mutant mice were impaired in hippocampal-dependent spatial learning and contextual fear conditioning tasks. Our studies indicate that the VGF C-terminal peptide TLQP62 modulates hippocampal synaptic transmission through a BDNF-dependent mechanism and that VGF deficiency in mice impacts synaptic plasticity and memory in addition to depressive behavior.
\end{abstract}

Key words: BDNF; VGF; contextual fear conditioning; depression; LTD; LTP; neuropeptide; tPA

\section{Introduction}

Growth factors in general, and brain-derived neurotrophic factor (BDNF) in particular, play critical roles in the nervous system to regulate neuronal development and survival, axonal outgrowth, synaptogenesis, and synaptic plasticity. Consistent with the global effects of BDNF on CNS development and wiring, and contributions to nervous system function in the adult, altered BDNF expression is associated with altered behavior. For example, a coding sequence variant ( $\mathrm{Val}{ }^{66} \mathrm{Met}$ ) in the human BDNF gene is associated with cognitive and behavioral deficits and childhood-onset mood disorder (Strauss et al., 2005), and BDNF deficiency in mice results in abnormal hippocampal associative memory (Gorski et al., 2003). In addition, neurotrophic growth factors also play a role in the pathophysiology of depression ( Du-

Received June 27, 2008; revised Aug. 15, 2008; accepted Aug. 18, 2008.

This work was supported in part by awards from National Alliance for Research on Schizophrenia and Depression (S.R.J.S.) and the Hirschl Trust Foundation (C.M.A.) and National Institutes of Health Grants MH065635 (C.M.A.), MH074736 (C.M.A.), MH065658 (M.L.S.), MH073689 (M.L.S.), MH075783 (G.W.H.), DK071308 (S.R.J.S.), and MH083496 (S.R.J.S.). We thank Carla Montgomery for technical assistance and Drs. Andrea Levi and Roberta Possenti for generously providing the TLQP21 and scrambled control peptides.

Correspondence should be addressed to Dr. Stephen R. J. Salton, Department of Neuroscience, Box 1065, Mount Sinai School of Medicine, One Gustave L. Levy Place, New York, NY 10029. E-mail: stephen.salton@mssm.edu.

S. Tronel's present address: Magendie Neurocenter, Inserm U862, Université de Bordeaux, F-33077 Bordeaux, France.

DOI:10.1523/JNEUROSCI.3145-08.2008

Copyright $\odot 2008$ Society for Neuroscience $\quad$ 0270-6474/08/289857-12\$15.00/0 man, 2005). Decreased BDNF levels are found in depressed patients (Shimizu et al., 2003; Karege et al., 2005), expression of BDNF and its receptor TrkB are regulated by electroconvulsive seizure therapy (ECT) and antidepressants (Newton et al., 2003; Farmer et al., 2004), BDNF infusion into the hippocampus or lateral ventricles produces antidepressant responses (Siuciak et al., 1997; Shirayama et al., 2002), and BDNF-TrkB signaling is required for antidepressant efficacy in the forced swim test (Saarelainen et al., 2003; Monteggia et al., 2004). Thus, in the hippocampus, BDNF signaling modifies depressive behavior, and a large number of studies demonstrate additional roles for BDNF/TrkB pathways in spatial memory and conditioned fear avoidance tasks, as well as the regulation of synaptic plasticity and the induction of long-term potentiation (LTP) (Poo, 2001; Gorski et al., 2003; Liu et al., 2004).

These varied functions of BDNF depend on genes or gene products that are regulated by this neurotrophin at a transcriptional, translational, or posttranslational level. For example the transcription factor cAMP response element-binding protein (CREB), which plays a critical role in memory consolidation, is activated by BDNF, but few downstream target genes have been identified that are induced by BDNF and transcriptionally regulated by CREB and contribute to memory and behavior. Previous studies have identified the BDNF- and CREB-regulated gene $v g f$ (nonacronymic), which encodes a secreted neuronal protein and 
peptide precursor that is highly conserved among mammals and has a zebrafish homolog, as a potentially important mediator of some of these actions. Hippocampal VGF expression is induced by ECT (Newton et al., 2003) and exercise (Duman, 2005; Hunsberger et al., 2007), both of which produce antidepressant responses, as well as by neuronal activity and seizure (Snyder et al., 1998b). In primary hippocampal neurons, BDNF induces VGF expression (Bonni et al., 1995; Alder et al., 2003), and this is associated with increased VGF transcript levels in the hippocampus after paired but not unpaired eye-blink conditioning, a hippocampal-dependent learning task (Alder et al., 2003). In addition, synthetic VGF C-terminal peptides TLQP62 and AQEE30 (designated by the $\mathrm{N}$-terminal four amino acids and the length) have been found to increase the synaptic activity of cultured hippocampal cells (Alder et al., 2003) and, very recently, to regulate depressive behavior in rodents (Hunsberger et al., 2007; ThakkerVaria et al., 2007), suggesting that VGF modulates hippocampal synaptic plasticity.

To directly test whether VGF expression is required for specific hippocampal learning tasks in vivo, we performed behavioral analyses of VGF knock-out mice. Homozygous VGF knock-out mice are lean and hypermetabolic and resist developing obesity and diabetes (Hahm et al., 2002; Watson et al., 2005). Although brain and spinal cord anatomy is grossly normal in VGF mutant mice (Hahm et al., 1999), neither hippocampal function nor hippocampal-dependent behavior has been examined previously. Here we report that VGF knock-out mice perform poorly in a spatial, but not a cued, version of the Morris water maze, a hippocampal-dependent memory task, and both heterozygous and homozygous knock-outs exhibit abnormal contextual fear conditioning. LTP in hippocampal slices from VGF knock-out mice appeared normal, but long-term depression (LTD) could not be induced. In addition, application of the VGF-derived C-terminal peptide TLQP62 was found to induce a transient potentiation in rat and mouse hippocampal slices via a BDNFdependent mechanism. Our data suggest that this secreted protein and peptide precursor regulates hippocampal function, depressive behavior, and memory, at least in part through modulation of BDNF secretion, processing, or signaling.

\section{Materials and Methods}

Strains used for behavioral studies and electrophysiology. Mouse behavioral and hippocampal slice experiments were performed on a previously described VGF knock-out mouse line (Hahm et al., 1999, 2002). To generate this line, R1 embryonic stem (ES) cells were transfected with a targeting construct that replaced the entire VGF coding sequence with a PGKneo cassette; ES cell clones having undergone homologous recombination at the $V g f$ locus were used to generate mice on a mixed $129 / \mathrm{SvJ} / \mathrm{C} 57 \mathrm{BL} / 6$ background with germ-line ablation of one, both, or neither $V g f$ allele(s) (Hahm et al., 1999). Heterozygous $V g f^{+} / V g f^{-}$mice were backcrossed with C57BL/6 mice (The Jackson Laboratory) for 10 generations, and, because $V g f^{-} / V^{-}$mice on either background are infertile, the resulting heterozygous $V g f^{+} / V g f^{-}$mice were inbred to yield wild-type and heterozygous and homozygous VGF knock-out mice for the experiments described below. A subset of our electrophysiological experiments were performed in parallel using hippocampal slices from a second VGF knock-out mouse line, generated as described previously (Valenzuela et al., 2003), in which the entire VGF coding sequence was ablated in the germ line and replaced by lacZ reporter and PGK-neo cassettes (provided by Regeneron Pharmaceuticals). On a C57BL/6 background, VGF knock-out mice from both lines are small, lean, and hypermetabolic with markedly reduced fat stores, identical in phenotype to mixed-background VGF mutant mice (Hahm et al., 2002), but, unlike hyperactive mixed-background knock-out mice, have normal locomotor activities (E. Watson, H. Okamoto, M. Sleeman, and S. Salton, unpub- lished data). Animals were provided food and water ad libitum, and all animal studies were conducted in accordance with the Guidelines for the Care and Use of Experimental Animals, using protocols approved by the Institutional Animal Care and Use Committee of Mount Sinai School of Medicine.

Hippocampal slice preparation and electrophysiology. Hippocampal slices $(350 \mu \mathrm{m})$ were prepared from 4- to 6-week-old Sprague Dawley rats (Charles River Laboratories) or 4- to 10-week-old VGF homozygous knock-out $\left(V g f^{-} / V g f^{-}\right)$, heterozygous knock-out $\left(V g f^{+} / V g f^{-}\right)$, and wild-type $\left(V g f^{+} / V g f^{+}\right)$mice, all on a C57BL/6 background. Generally, one hippocampal slice per rat and two to three slices per mouse were prepared. Slices were perfused with Ringer's solution containing the following (in mM): $125.0 \mathrm{NaCl}, 2.5 \mathrm{KCl}, 1.3 \mathrm{MgSO}_{4}, 1.0 \mathrm{NaH}_{2} \mathrm{PO}_{4}, 26.2$ $\mathrm{NaHCO}_{3}, 2.5 \mathrm{CaCl}_{2}$, and 11.0 glucose. The Ringer's solution was bubbled with $95 \% \mathrm{O}_{2} / 5 \% \mathrm{CO}_{2}$, at $32^{\circ} \mathrm{C}$ or room temperature (when indicated), during extracellular recordings (electrode solution, $3 \mathrm{~m} \mathrm{NaCl}$ ). Slices were maintained for $1 \mathrm{~h}$ before establishment of a baseline of field EPSPs (fEPSPs) recorded from stratum radiatum and stratum pyramidale (when indicated) in area CA1, evoked by stimulation of the Schaffer collateral-commissural afferents ( $100 \mu$ s pulses every $30 \mathrm{~s}$ ) with bipolar tungsten electrodes placed into area CA3 (Bozdagi et al., 2000). Test stimulus intensity was adjusted to obtain fEPSPs with amplitudes that were one-half of the maximal response. The EPSP initial slope (millivolts per millisecond) was determined from the average waveform of four consecutive responses. Intracellular recordings of CA1 pyramidal neurons were performed with $3 \mathrm{M} \mathrm{KCl}$-filled microelectrodes. Input resistance was recorded from current-voltage relationships with $150 \mathrm{~ms}$ current pulses of -0.6 to $0.6 \mathrm{nA}$. Synthetic VGF peptides TLQP62, TLQP21, AQEE30, and LEGS25amide (0.1, 1, and $10 \mu \mathrm{M}), \mathrm{BDNF}(50 \mathrm{ng} / \mathrm{ml})(\mathrm{re}-$ combinant human met-BDNF; prepared by Amgen and provided by Regeneron Pharmaceuticals; PeproTech; stored at $-70^{\circ} \mathrm{C}$ in $10 \mathrm{mg} / \mathrm{ml}$ of $150 \mathrm{~mm} \mathrm{NaCl}, 10 \mathrm{~mm} \mathrm{NaHPO}_{3}$ buffer, and $0.004 \%$ Tween 20 until use), K252a and K252b (100 nM to $1 \mu \mathrm{M}$; diluted in 0.05\% DMSO; Calbiochem), and PA STOP ( $2 \mu \mathrm{M}$; America Diagnostica) were bath applied for durations indicated in the figure legends. Using $10 \mu \mathrm{M}$ TLQP62, all slices exhibited a potentiation of at least $20 \%$ in fEPSP slope. For Trk-Fc fusion protein and function-blocking anti-p $75^{\text {NTR }}$ experiments, slices were incubated with fusion protein $(5 \mu \mathrm{g} / \mathrm{ml}$; Regeneron Pharmaceuticals; R\&D Systems) or anti-p75 ${ }^{\text {NTR }}$ (rabbit polyclonal 9651, 1:100 dilution; generously provided by Dr. Moses Chao, New York University School of Medicine, New York, NY) (Huber and Chao, 1995; Skoff and Adler, 2006), for $2 \mathrm{~h}$, and then were transferred to the recording chamber. Paired-pulse responses were measured with interstimulus intervals (ISIs) of 10 and 50 $\mathrm{ms}$ and are expressed as the ratio of the average responses to the second stimulation pulse (FP2) to the first stimulation pulse (FP1).

LTP was induced by a high-frequency stimulus (four trains of $100 \mathrm{~Hz}$, $1 \mathrm{~s}$ stimulation separated by $5 \mathrm{~min}$ ), theta-burst stimulation (TBS) (10 bursts of four pulses at $100 \mathrm{~Hz}$ separated by $200 \mathrm{~ms}$ ), or a single $100 \mathrm{~Hz}$ stimulation, with a success rate $>90 \%$ for control and genetically modified mice with all stimulation protocols (one wild-type and one heterozygous slice failed to exhibit LTP of at least $20 \%$ increase in amplitude, and these were excluded from the analysis). To induce LTD, Schaffer collaterals were stimulated by a low-frequency stimulus ( 900 pulses at 1 $\mathrm{Hz}$ for $15 \mathrm{~min}$ ). LTD of at least $20 \%$ decrease in amplitude was induced in all control and heterozygous slices. Data are expressed as means $\pm \mathrm{SD}$, and statistical analyses were performed using ANOVA or Student's $t$ test, in which $p<0.05$ was considered significant.

Morris water maze. Mice were tested in a water maze task to assess hippocampal-dependent (uncued) and hippocampal-independent (cued) learning. Previously described VGF knock-out mice (Hahm et al., 1999) were backcrossed $>10$ generations onto a C57BL/6 background, and 3- to 4-month-old male homozygous knock-out ( $\left.V g f^{-} / V g f^{-}\right)$, heterozygous knock-out $\left(V g f^{-} / V g f^{+}\right)$, and wild-type $\left(V g f^{+} / V g f^{+}\right)$mice were used in these experiments. The water maze was a circular tank (170 $\mathrm{cm}$ diameter, $63.5 \mathrm{~cm}$ height) filled $38 \mathrm{~cm}$ deep with water $\left(23 \pm 1^{\circ} \mathrm{C}\right)$ that was positioned in a room that contained a number of visual clues. White tempera paint (Dick Blick Paint Materials) was added to the water to make it opaque. A clear platform $(10.5 \times 10.5 \mathrm{~cm})$ was submerged 2 $\mathrm{cm}$ below the surface of the water for hidden and cued trials. For cued 
trials, the platform location was signaled by a black cue on top of the platform and by another black cue suspended $35 \mathrm{~cm}$ above the platform. These cues were removed during hidden trials. A custom-made computerized tracking system recorded and analyzed the swim paths. Mice were trained for 1 week until their performance reached a plateau. Twelve swims were then performed over $4 \mathrm{~d}$ and averaged, and the swim path was integrated to obtain total distance swam. Cued and uncued trials were interleaved as follows: days 1 and 2, cued, uncued, uncued, cued, cued, uncued; days 3 and 4, uncued, cued, cued, uncued, uncued, cued.

On day 4, the target platform was removed and a 60 s probe trial was performed. Search paths were tracked, and time spent in two regions was recorded: the target region was a circular region of $20 \mathrm{~cm}$ diameter centered on the location of the target platform, and the nontarget region was a circular region of $20 \mathrm{~cm}$ placed at the center of the maze. These data were used to calculate a performance index, essentially as described previously (Bunsey and Eichenbaum, 1996; Brun et al., 2001), which we called a "spatial learning index": (time over target - time $\left._{\text {over nontarget }}\right) /$ $\left(\right.$ time $_{\text {over target }}+$ time $\left._{\text {over nontarget }}\right)$. A high spatial learning index indicates that more time was spent near the target platform relative to the nontarget region.

Contextual fear conditioning. Male 3- to 4-month-old homozygous knock-out $\left(V g f^{-} / V g f^{-}\right)$, heterozygous knock-out $\left(V g f^{-} / V g f^{+}\right)$, and wild-type $\left(V g f^{+} / V_{g} f^{+}\right)$mice (Hahm et al., 1999), backcrossed onto a homogeneous C57BL/6 background, were used for these studies. Fear conditioning took place in an observation chamber $(30 \times 24 \times 21 \mathrm{~cm}$; MED Associates). The chamber consisted of a Plexiglas box (sidewalls, rear wall, ceiling, and hinged front door). The floor of the chamber consisted of 36 stainless steel rods ( $3 \mathrm{~mm}$ in diameter) spaced $8 \mathrm{~mm}$ apart (center-to-center). Rods were wired to a shock source and solid-state grid scrambler (MED Associates) for the delivery of foot shock. A $15 \mathrm{~W}$ house light was mounted on the wall. Mice were handled in the room where conditioning took place for $5 \mathrm{~min}$ each day for $6 \mathrm{~d}$. On the training day, they were placed into the chamber, the house light was turned on, and, after a 3 min acclimatizing period, they received five shocks at $62 \mathrm{~s}$ intervals. Each shock was $0.75 \mathrm{~mA}$ and $2 \mathrm{~s}$ duration. Mice were left in the conditioning chamber for $30 \mathrm{~s}$ after termination of the procedure and then returned to their home cage. Twenty-four hours later, mice were placed into the conditioning chamber and observed for 3 min. Freezing behavior was recorded during conditioning and testing sessions. Freezing was defined as the absence of any visible movements other than those necessary for respiration and was scored according to a $5 \mathrm{~s}$ time sampling procedure. Observations scored as freezing were summed and converted to a percentage.

\section{Results}

Contextual fear conditioning is impaired in VGF mutant mice VGF mRNA and immunoreactivity have been localized in the central amygdala (van den Pol et al., 1994; Snyder and Salton, 1998; Snyder et al., 1998a) in which VGF expression is upregulated by exogenous BDNF (Eagleson et al., 2001). We therefore examined an emotional learning paradigm, contextual fear conditioning, which requires both an intact hippocampus and amygdala (Phillips and LeDoux, 1992; Goosens and Maren, 2001), in homozygous VGF mutant, heterozygous VGF mutant, and wildtype mice. Published studies have identified a critical role for BDNF in contextual fear conditioning, specifically in the hippocampus (Liu et al., 2004). Because previous studies did not reveal impaired nociception in VGF mutant compared with wildtype mice (Hahm et al., 1999), measured by heat-induced tailflick latency, we used a foot-shock paradigm to test contextual fear conditioning (see Materials and Methods). To assess memory for contextual fear conditioning, we tested mice in the same context, $24 \mathrm{~h}$ after training. As shown in Figure 1, both homozygous and heterozygous VGF knock-out mice froze significantly less than wild-type mice (ANOVA, $F_{(2,17)}=15.53, p<0.0001$; Newman-Keuls post hoc test, $p<0.001$ for both groups). No differences in freezing behavior among the three groups were noted during the training session, and locomotor activity of these

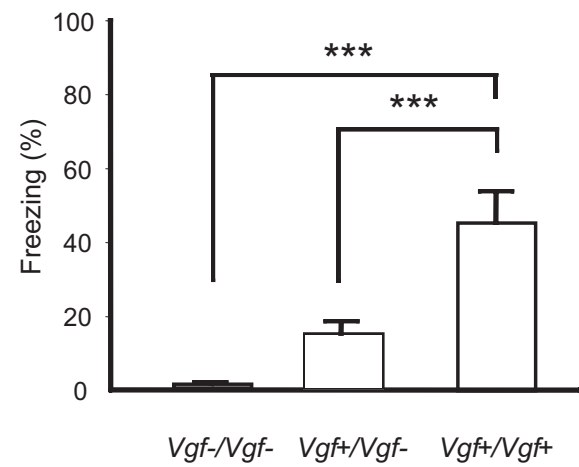

Figure 1. Homozygous and heterozygous VGF knock-out mice have impaired contextual fear conditioning compared with wild-type mice. Homozygous Vgf ${ }^{-} \mathrm{Vgf}^{-}(n=5)$, heterozygous $\mathrm{Vgf}^{+} / \mathrm{Vgf}^{-}(n=8)$, and wild-type $\mathrm{Vgf}^{+} / \mathrm{Vgf}^{+}(n=7)$ male mice were trained and tested for contextual fear conditioning as described in Materials and Methods. Data are expressed as the mean \pm SEM percentage of time spent freezing during the 3 min period of testing, $24 \mathrm{~h}$ after training $\left({ }^{* *} p<0.001\right)$.

three groups of mice on a homogeneous C57BL/6 background was the same (Hunsberger et al., 2007) (Watson, Okamoto, Sleeman, and Salton, unpublished data).

\section{Hippocampal-dependent spatial learning is impaired in VGF mutant mice}

We next tested mice for hippocampal-dependent (noncued, hidden platform) and hippocampal-independent (cued, visible platform) learning using the Morris water maze (see Materials and Methods). After training, VGF homozygous and heterozygous knock-out and wild-type mice received four trials per day on 4 successive days, with performance on each day computed by averaging the four trials. Performance of VGF homozygous mutant mice was impaired on the uncued learning task compared with wild-type mice, reaching significance at day 4; compared with wild-type mice, VGF knock-out mice took more time to reach the hidden platform (latency) (supplemental Fig. 1, available at www.jneurosci.org as supplemental material) and traveled a greater distance (Fig. 2C,D), whereas swimming speed was not significantly different, nor did it vary throughout the $4 \mathrm{~d}$ experiment (supplemental Fig. 1, available at www.jneurosci.org as supplemental material). Cued learning of VGF homozygous and heterozygous mutant mice and wild-type mice was not significantly different (Fig. 2C). On day 4, the platform was removed and a $60 \mathrm{~s}$ probe trial was performed. Search paths were tracked, and time spent in the target region (a $20 \mathrm{~cm}$ circle centered over the hidden platform) was compared with time spent in a nontarget region (a $20 \mathrm{~cm}$ circle placed at the center of the maze). These data were used to calculate a performance index for each genotype, essentially as described previously (Bunsey and Eichenbaum, 1996; Brun et al., 2001), which we refer to as a spatial learning index (see Materials and Methods). A high spatial learning index indicates a search path in which more time was spent near the target platform region. VGF homozygous knock-out mice were found to have a significantly lower learning index than wild-type mice (Bonferroni's correct pairwise comparison, $p=$ $0.025 ; n=5$ mice of each genotype per group) (Fig. $2 E, F$; see legend for additional details of statistical analyses performed).

\section{Long-term potentiation in hippocampal slices from VGF knock-out mice is indistinguishable from wild-type mice, but long-term depression is impaired}

Previous studies have demonstrated VGF mRNA expression in the developing and adult hippocampus (van den Pol et al., 1994; 
A

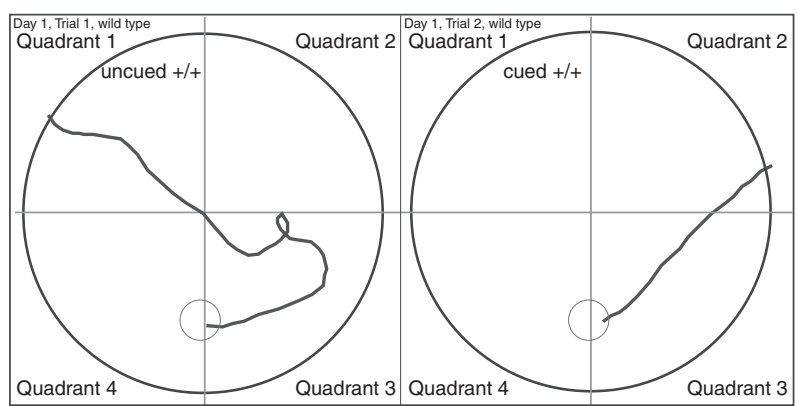

C

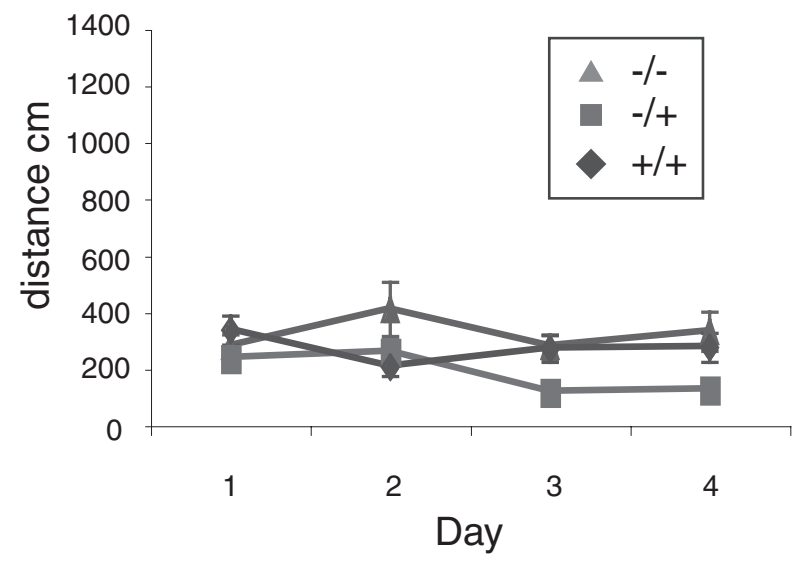

$E$
B

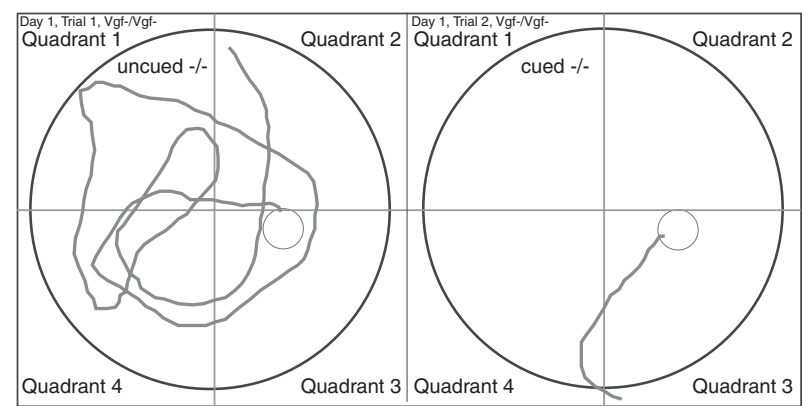

$\mathrm{D}$

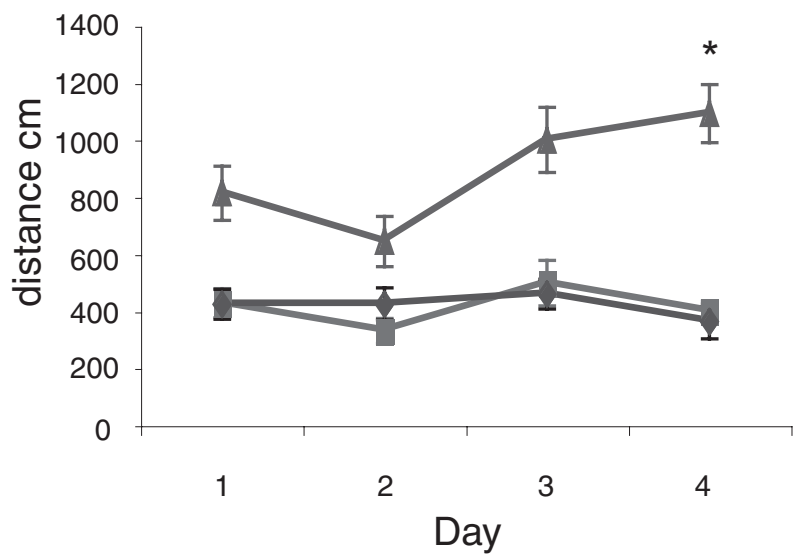

$\mathrm{F}$
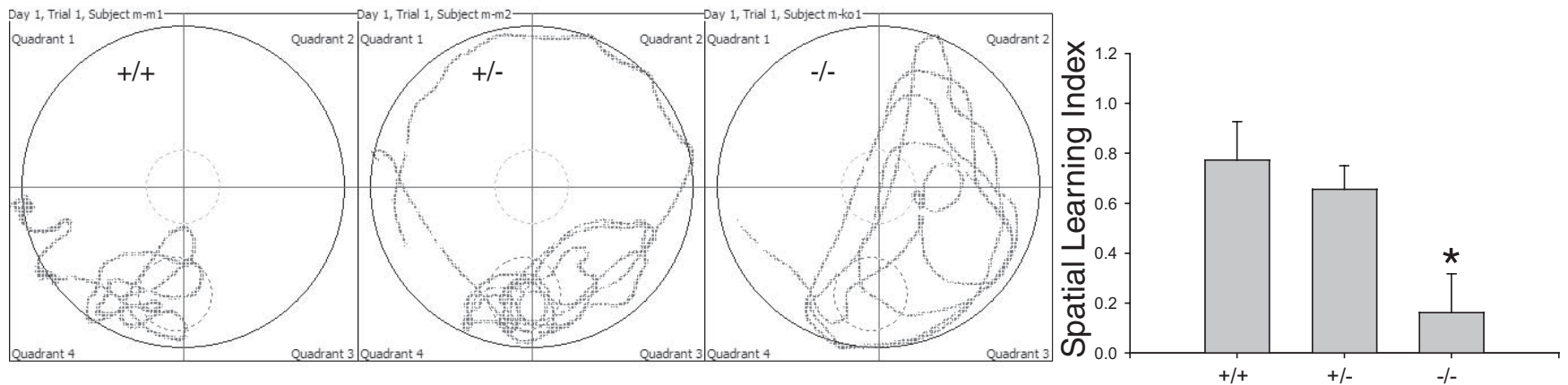

Figure 2. VGF homozygous mutant mice have impaired performance in the Morris water maze. Mice were tested in the Morris water maze as described in Materials and Methods. Performance in the four daily cued and uncued trials was evaluated by video camera, and parameters were averaged for each day (days $1-4)$. In $\boldsymbol{A}$ and $\boldsymbol{B}$, sample computer-generated tracings of swim paths are shown for wild-type $(\boldsymbol{A})$ and VGF knock-out $(\boldsymbol{B})$ mice in uncued (left) and cued (right) trials. $\boldsymbol{C}, \boldsymbol{D}$, Distance traveled (centimeters) ( $\boldsymbol{C}$, cued; $\boldsymbol{D}$, uncued) was quantified for each genotype on each day (ANOVA, mean \pm SEM; $n=5$ mice of each genotype per group; ${ }^{*} p \leq 0.05$ ). On day 4 , the target platform was removed, and a $60 \mathrm{~s}$ probe trial was performed. $\boldsymbol{E}$, Search paths were tracked, and time spent in the target region of the maze (a circular region of $20 \mathrm{~cm}$ diameter centered on the location of the target platform) and the nontarget region (a circular region of $20 \mathrm{~cm}$ diameter placed at the center of the maze) was quantified. $\boldsymbol{F}$, Probe trial performance was measured by calculating a spatial learning index: (time ${ }_{\text {over }}$ target time $\left._{\text {over nontarget }}\right) /\left(\right.$ time $_{\text {over target }}+$ time $\left._{\text {over nontarget }}\right)$. ANOVA demonstrated a significant effect of genotype on learning index $\left(F_{(2,12)}=5.615 ; p=0.019\right)$, which was confirmed with a nonparametric test (Kruskal-Wallis rank sum, $p=0.049$ ). Bonferroni's correct pairwise comparisons revealed a significant difference between knock-out and wild-type learning indices ( $p=0.025)$, but differences between wild-type and heterozygote $(p=1.000)$ and knock-out and heterozygote $(p=0.076)$ indices were not significant.

Lombardo et al., 1995; Snyder and Salton, 1998; Snyder et al., 1998a), specifically in the pyramidal cell layer of the adult CA1CA3 regions, and in dentate gyrus granule cells in which it is inducible by kainic acid-induced seizures (Snyder et al., 1998b). In the hippocampus, VGF immunoreactivity is associated with cells in the pyramidal cell layer of CA1 and CA 3 and in the hilar region of the dentate gyrus, internal to the granule cell layer, generally in cells that may be inhibitory GABAergic neurons based on morphology and location (van den Pol et al., 1994). Because previous studies did not suggest that targeted ablation of VGF affected the gross morphology of the brain including adult hippocampus (Hahm et al., 1999) but analysis revealed significant deficits in hippocampal-dependant behavior (Figs. 1, 2), we tested whether VGF is required for the induction of LTP or LTD of synaptic transmission.

In the first set of experiments, LTP was induced by tetanic 
A
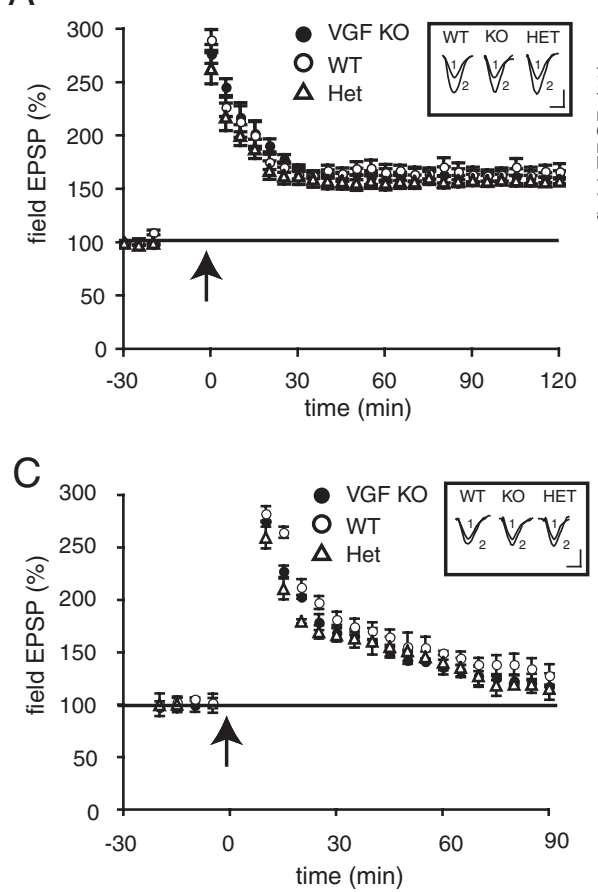

B

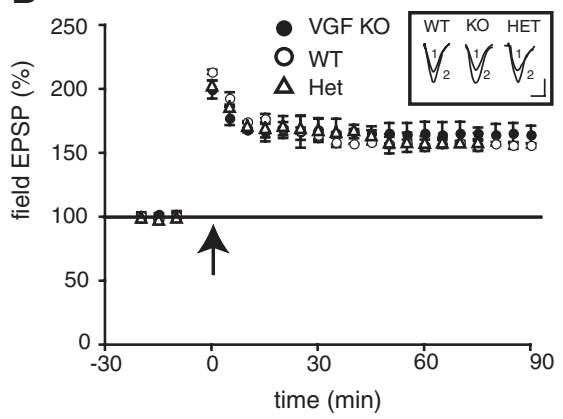

D

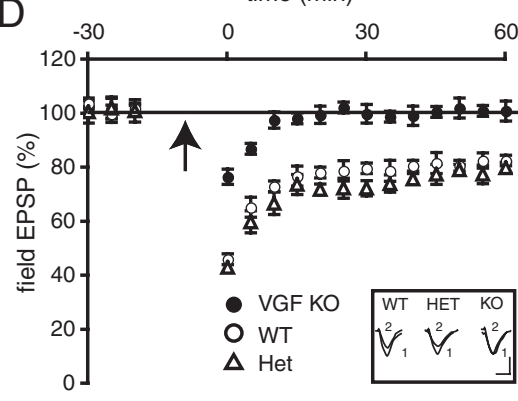

Figure 3. LTP in VGF mutant mice is indistinguishable from wild-type mice, but LTD is impaired in homozygous VGF knock-out mice. In $A$, to determine whether VGF modulates the generation of LTP at Schaffer collateral-CA1 hippocampal synapses, LTP was induced by tetanic stimulation ( $4 \times 1 \mathrm{~s}$ trains, $100 \mathrm{~Hz}$, separated by $5 \mathrm{~min}$ ) to the Schaffer collaterals in hippocampal slices taken from homozygous $\mathrm{Vgf}^{-} / \mathrm{Ngf}^{-}$knock-out mice (filled circles), heterozygous $\mathrm{Vgf}^{-} \mathrm{Ngf}^{+}$mice (open triangles), and wild-type mice (open circles) ( $n=4$ mice per group, $2-3$ slices per animal), and field EPSP slope in CA1 was determined during the 120 min recording period after tetanus. The inset shows representative EPSP traces that were obtained for each genotype, recorded before (1) and 120 min after (2) tetanic stimulation (calibration: $10 \mathrm{~ms}, 0.5 \mathrm{mV}$ ). In $\boldsymbol{B}$, LTP induced by theta-burst stimulation (10 bursts of four pulses at $100 \mathrm{~Hz}$ separated by $200 \mathrm{~ms}$ ) was found to be comparable in hippocampal slices from wild-type, heterozygous, and homozygous VGF knock-out mice [inset, representative traces for each genotype, recorded before (1) and 90 min after (2) theta-burst stimulation]. In C, no significant differences among the three genotypes were detected when early-phase LTP was stimulated in hippocampal slices by a single $100 \mathrm{~Hz}$ pulse of $1 \mathrm{~s}$ duration [inset, representative traces for each genotype, recorded before (1) and 90 min after (2) stimulation]. In contrast, in D, LTD induced by low-frequency stimulation was significantly reduced in hippocampal slices from homozygous VGF knock-out mice compared with wild-type or heterozygous VGF mutant mice $(n=$ 2- 4 mice per group, $2-3$ slices per animal; $p<0.01$ ) [inset, representative traces for each genotype, recorded before (1) and 60 min after (2) LFS stimulation]. All field EPSP measurements shown are mean \pm SD (calibration: $10 \mathrm{~ms}, 0.5 \mathrm{mV}$ ). KO, Knock-out; WT, wild type; Het, heterozygous.

stimulation of the Schaffer collaterals (4 trains of $100 \mathrm{~Hz}$ separated by $5 \mathrm{~min}$, a stimulation protocol that induces both early LTP and protein synthesis-dependent late-phase LTP in hippocampal slices), in slices taken from heterozygous and homozygous VGF knock-out mice and from wild-type mice (Fig. $3 A$ ). The induction and maintenance of LTP were not significantly different between wild-type and either heterozygous or homozygous mutant mouse hippocampal slices over the 120 min time course after tetanic stimulation (average percentage of baseline 120 min after tetanus: $-/-, 161 \pm 5 \% ;+/-, 158 \pm 4 \% ;+/+$, $167 \pm 6 \%$; mean $\pm \mathrm{SD} ; n=4$ mice per group; ANOVA, $p>0.1$ ). In another set of experiments, we further tested LTP induced by TBS (Fig. 3B) (10 bursts of four pulses at $100 \mathrm{~Hz}$ separated by 200 $\mathrm{ms}$ ) (average percentage of baseline $90 \mathrm{~min}$ after TBS: $-/-$, $164 \pm 6 \% ;+/-, 159 \pm 2 \% ;+/+, 156 \pm 32 \%$; mean \pm SD; $n=$ 4 mice per group, $2-3$ slices per mouse; ANOVA, $p>0.05$ ) and early-phase LTP by stimulating with a single $100 \mathrm{~Hz}$ pulse of $1 \mathrm{~s}$ duration (average percentage of baseline $60 \mathrm{~min}$ after tetanus: $-/-, 136.4 \pm 6.4 \%$; +/-, $139.8 \pm 4.8 \%:+/+, 141 \pm 6.8 \%$; mean $\pm \mathrm{SD} ; n=4$ mice per group, $2-3$ slices per mouse; ANOVA, $p>0.05$ ) (Fig. 3C). There were no significant differences among the three genotypes with these stimulation para- digms. Tests for basal synaptic input-output relationships also indicated that there were no significant differences in synaptic transmission in the Schaffer collateral pathway among genotypes, nor was paired-pulse facilitation (PPF), a form of short-term plasticity, found to be affected (FP2/FP1 $=1.27 \pm 0.05$ for $-/-$ homozygous knock-out, $1.26 \pm 0.04$ for $+/$ - heterozygous knock-out, and $1.26 \pm 0.03$ for $+/+$ wild type; mean $\pm \mathrm{SD} ; n=4$ mice per group, $2-3$ slices per mouse; $p=0.4$ ). In contrast, LTD induced by lowfrequency stimulation (LFS) was significantly reduced in VGF knock-out slices (Fig. 3D) (field EPSP: $-/-, 98.2 \pm 2 \%$; $+/-, 73.8 \pm 3.6 \%$; +/+, $76.9 \pm 3.7 \%$, measured 15 min after LFS; $-/-, 101 \pm$ $2 \% ;+/-, 79.9 \pm 2 \% ;+/+, 82.6 \pm 3.6 \%$, measured 60 min after LFS; mean \pm SD; $n=2-4$ mice per group, $2-3$ slices per mouse; ANOVA, $p<0.01$ ).

\section{VGF-derived TLQP62 peptide potentiates CA1 fEPSP}

VGF-derived C-terminal peptides have been shown to increase synaptic activity in cultured hippocampal neurons (Alder et al., 2003). Because VGF mutant mice have abnormalities in hippocampal-dependent learning, we investigated the effects of VGF-derived peptides on EPSPs in hippocampal slices. Rat hippocampal slices were treated with the VGF-derived C-terminal TLQP62 peptide (designated by the first four amino acids and length), and field EPSP slope in the CA1 region of the hippocampus was determined over a range of peptide concentrations. At $10 \mu \mathrm{M}$, TLQP62 application initiated potentiation within 5 min, reaching $288 \pm 10 \% 10 \mathrm{~min}$ after application and gradually decaying back to baseline within 40-60 min after washout (Fig. 4A).

Stimulus intensity (in milliamperes) was plotted against the slope of fEPSPs (millivolts per millisecond) for a sampling of control slices, slices treated with TLQP62, and TLQP62-treated slices that were analyzed $60 \mathrm{~min}$ after peptide washout (Fig. $4 B$ ) $(n=6)$. The mean slope of the input-output function shown in Figure $4 B$, calculated from each slope for the control condition, was $2.25 \pm 0.3$, which was not significantly different from that after TLQP62 washout $(1.85 \pm 0.3 ; p=0.3)$. These input-output curves demonstrated that there was an increase in fEPSP slope across all stimulation currents with TLQP62 treatment, which was followed by a recovery to baseline within $\sim 90 \mathrm{~min}$ after peptide washout, indicating that TLQP62 application did not produce lasting changes in synaptic transmission. The stimulus intensity for the $50 \%$ maximum response was $84.7 \pm 1.1 \mu \mathrm{A}$ for TLQP62-treated slices $60 \mathrm{~min}$ after washout versus $83.6 \pm 1.2 \mu \mathrm{A}$ for controls $(n=6 ; p>0.05)$. PPF, a form of plasticity that is thought to reflect presynaptic mechanisms, was not significantly altered after application of TLQP62 (FP2/FP1 $=1.45 \pm 0.18$ and $1.42 \pm 0.15$, before and after TLQP62 treatment, respectively; ISI of $50 \mathrm{~ms} ; n=6 ; p>0.05, t$ test). When two pulses separated by a 
$10 \mathrm{~ms}$ interval are delivered to the Schaffer collateral//commissural pathway in CA1, the amplitude of the response recorded at the stratum pyramidale evoked by the second stimulation pulse is lower than the amplitude of the first response [pairedpulse inhibition (PPI)], which is attributed to increased activation of local inhibitory interneurons, releasing the neurotransmitter GABA (Davies et al., 1990). When TLQP62 was applied to hippocampal slices, PPI, a measure of circuit excitability, did not differ from the untreated control $(\mathrm{FP} 2 / \mathrm{FP} 1=0.71 \pm 0.06$ and $0.69 \pm 0.08$, before and after TLQP62 treatment, respectively; ISI of $10 \mathrm{~ms} ; n=6 ; p>0.05, t$ test), suggesting that TLQP62 does not alter hippocampal excitability through modulation of GABAergic transmission (for representative traces, see supplemental Fig. 2C, available at www.jneurosci.org as supplemental material). In addition, resting membrane potential and input resistance were not significantly changed after TLQP62 application, indicating no effect of TLQP62 on the intrinsic membrane properties of CA1 pyramidal neurons. High-resistance microelectrode recordings of 16 CA1 neurons each from control ( $n=4$ slices) and TLQP62-treated ( $n=4$ slices) slices showed that the average input resistance $(36 \pm 2.6 \mathrm{M} \Omega$ ) was not significantly different from control $(37 \pm 3.2$ $\mathrm{M} \Omega$ ), nor were there significant differences between groups in the average resting membrane potential (millivolts) of CA1 neurons $(-68 \pm 0.3$ control vs $-67 \pm 0.2$ TLQP62 treated; Student's $t$ test, $p>0.05$ ).

The C-terminal VGF-derived peptides AQEE30 and TLQP21, N-terminal peptide LEGS25amide, and scrambled TLQP62 control peptide all produced little or no potentiation compared with TLQP62 over several concentrations tested (from 1 to $100 \mu \mathrm{M}$ ) (Fig. 4C,D). We further noted that pretreatment of hippocampal slices with its 21 amino acid C-terminally truncated peptide fragment TLQP21 abolished TLQP62-mediated synaptic potentiation (Fig. 4D), whereas a scrambled TLQP21 peptide had no effect (supplemental Fig. $2 A$, available at www.jneurosci.org as supplemental material). To determine whether TLQP21 contributed to the sustained phase of potentiation, we applied TLQP21 20 min after potentiation had been established. TLQP21 application after potentiation had been initiated had no effect (Fig. $4 D$ ), suggesting that TLQP21 antagonizes TLQP62 only during the induction of potentiation. Last, to test whether TLQP62-induced potentiation in rat hippocampal slices was comparable with mouse hippocampal slices, we applied TLQP62 to hippocampal slices from wild-type, heterozygous, and homozygous VGF mutant mice and noted similar potentiation to that in rat (Fig. $4 E)(p>0.05)$.
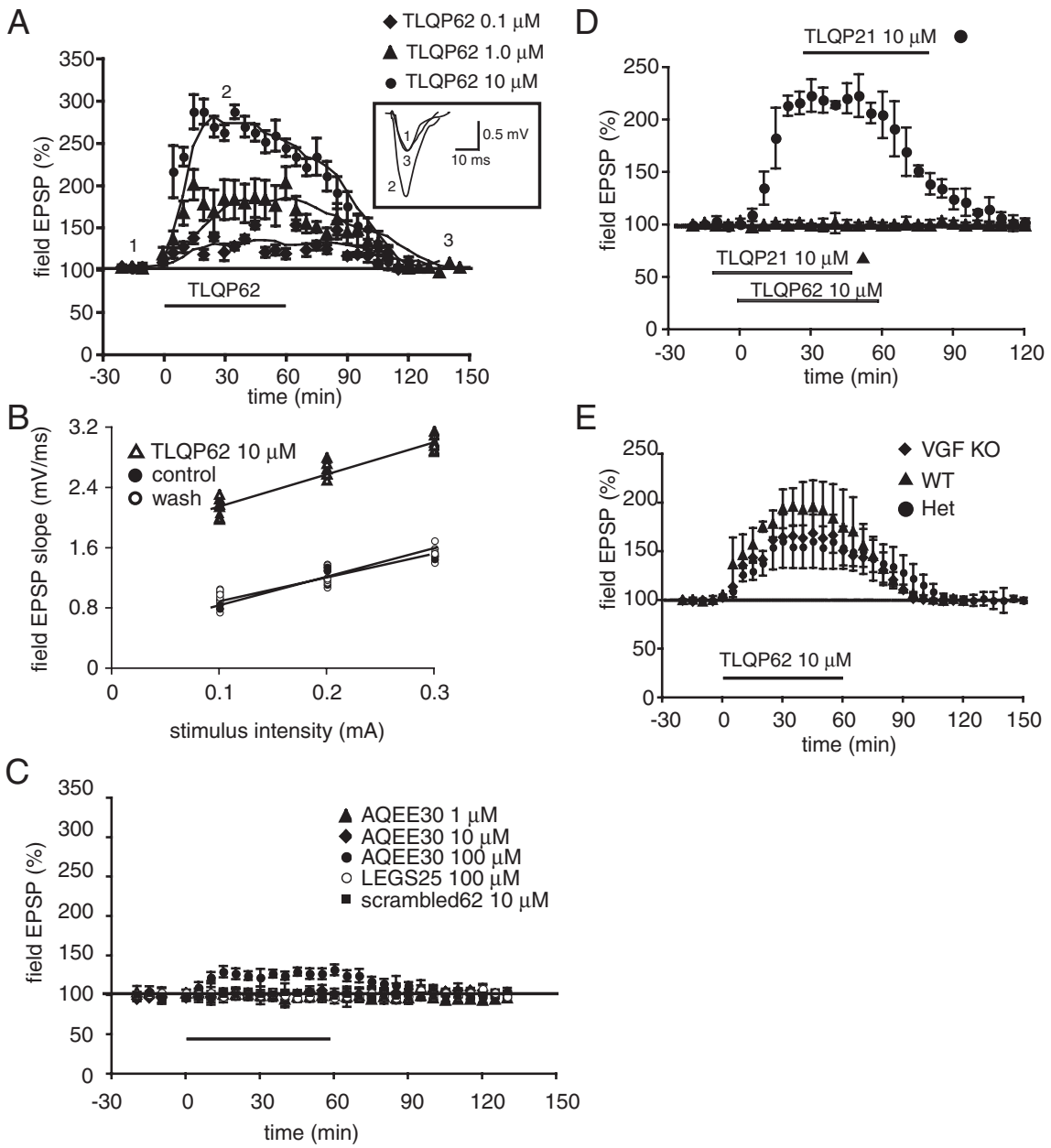

Figure 4. VGF-derived C-terminal peptide TLQP62 potentiates CA1 field EPSPs. In $\boldsymbol{A}$, hippocampal slices were treated with varying doses of TLQP62 (0.1-10 $\mu \mathrm{m})$, and fEPSP slope in the CA1 region was determined. The bar indicates the duration of TLQP62 treatment ( $n=6$ rats for each TLQP62 concentration tested). The inset in $A$ shows representative EPSP traces before (1), 30 min after (2), or $150 \mathrm{~min}$ after (3) initial exposure to $10 \mu \mathrm{M}$ TLQP62. In $\boldsymbol{B}$, input- output curves plotting stimulus intensity (millivolts per millisecond) are shown in control slices (filled circles), slices treated with 10 $\mu \mathrm{M}$ TLQP62 (open triangles), and 60 min after TLQP62 washout (open circles) ( $n=6$ rats). In C, VGF-derived peptides AQEE30 (1-100 $\mu \mathrm{M})$ and LEGS25amide (100 $\mu \mathrm{m}$; open circles) and a scrambled control TLQP62 peptide (10 $\mu \mathrm{M}$; filled squares) were truncated peptide TLQP21 blocked TLQP62-mediated potentiation, hippocampal slices were pretreated with TLQP21 (10 $\mu$ M; flled triangles) before administration of TLQP62 or were treated with TLQP21 after TLQP62-mediated potentiation had been (10 $\mu \mathrm{m}$; filled circles) ( $n=3$ rats). In $\boldsymbol{E}$, TLQP62 (10 $\mu \mathrm{m}$ ) was applied to hippocampal slices from wild type (WT) heterozygous $\mathrm{Vgf}^{+} \mathrm{Ngf}^{-}$(Het), and homozygous Vgf $\mathrm{Ngf}^{-}$(KO), and field EPSP slope in the CA1 region was determined. The means of the fEPSP slope at 60 min of TLQP62 treatment were as follows: $170 \pm 35 \%$ (WT), $160 \pm 27 \%$ (Het), and $167 \pm 27 \%$ (KO) $(n=2-4$ mice per genotype, $3-4$ slices per animal; $p>0.05$, ANOVA). All field EPSP measurements shown are mean \pm SD.

\section{VGF-derived peptide TLQP62 induces potentiation of CA1 field EPSPs via a BDNF-dependent mechanism}

Because increased VGF expression is associated with BDNFinduced plasticity (Bonni et al., 1995; Alder et al., 2003), we next examined whether the action of VGF to facilitate hippocampal synaptic transmission was mediated by signaling of a specific neurotrophic growth factor. Slices were incubated in TrkA-Fc, TrkB-Fc, TrkC-Fc, and Fc alone $(5 \mu \mathrm{g} / \mathrm{ml})$ for $2 \mathrm{~h}$ and then transferred to the recording chamber and perfused with TLQP62 for $60 \mathrm{~min}$. TLQP62-mediated potentiation was not observed in slices incubated with the BDNF scavenger TrkB-Fc $(p<0.01)$ (Fig. 5A), whereas pretreatment of slices with TrkA-Fc, which scavenges NGF, TrkC-Fc, which scavenges neurotrophin-3 (NT3 ), or control human Fc alone each had no significant effect ( $p>$ 0.05 ) on TLQP62-induced potentiation (Fig. 5A) (supplemental 

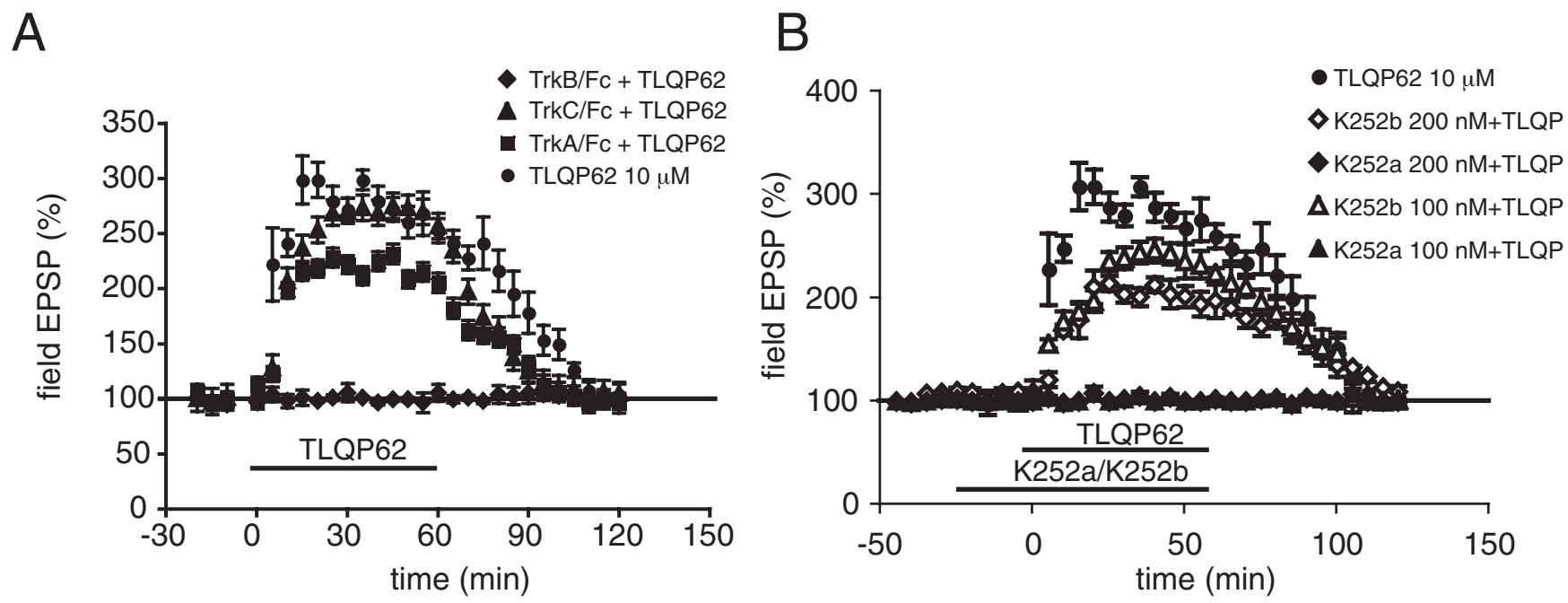

C
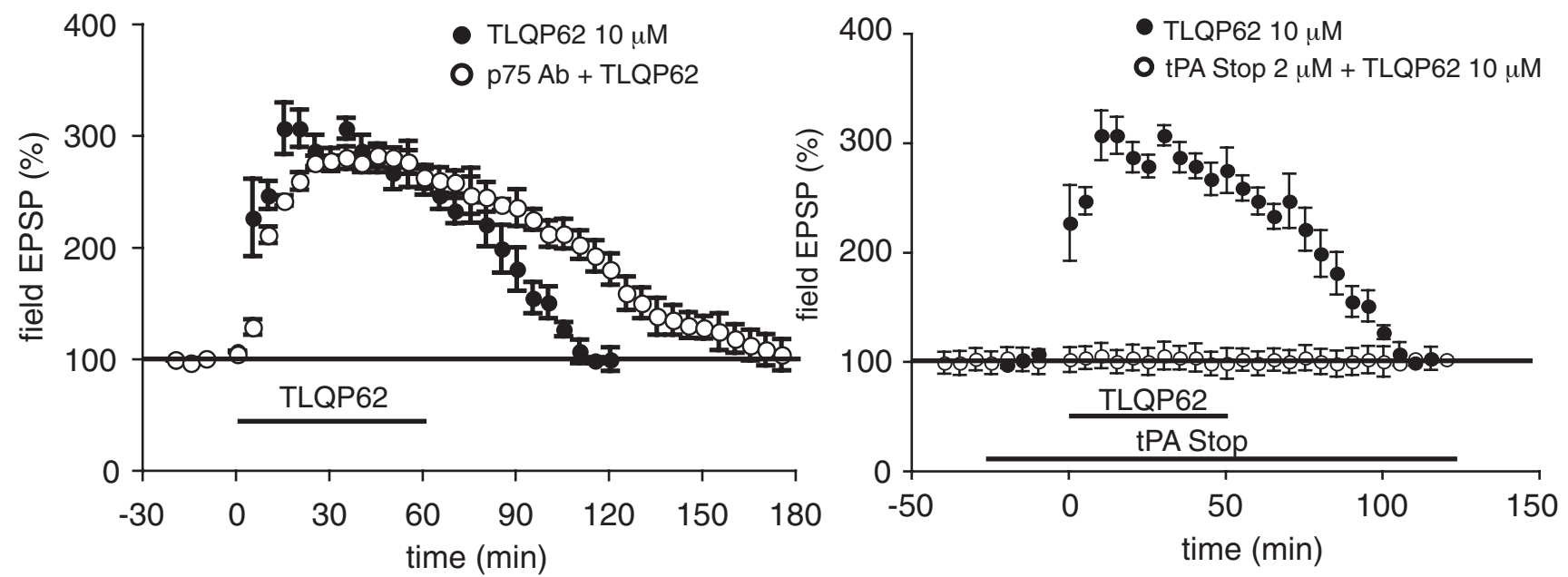

Figure 5. VGF-derived peptide TLQP62 enhances excitatory transmission in the CA1 region via a mechanism that is BDNF dependent and is blocked by inhibitors of Trk tyrosine kinase activity or tissue plasminogen activator (tPA), but not by function-blocking anti-p $75^{\mathrm{NTR}}$ antiserum. In $A$, hippocampal slices were incubated for $2 \mathrm{~h}$ in the BDNF scavenger TrkB-Fc ( $5 \mu \mathrm{g} / \mathrm{ml}$; diamonds), the NT-3 scavenger TrkC-Fc $(5 \mu \mathrm{g} / \mathrm{ml}$; triangles), the NGF-scavenger TrkA-Fc ( $5 \mu \mathrm{g} / \mathrm{ml}$; squares), or Ringer's solution (circles). After the $2 \mathrm{~h}$ incubation, slices were transferred to the recording chamber and were perfused with $10 \mu \mathrm{M}$ TLQP62 for $1 \mathrm{~h}$. In control experiments, treatment with $\mathrm{Fc}$ alone $(5 \mu \mathrm{g} / \mathrm{ml})$ had no effect on TLQP62-induced potentiation (supplemental Fig. $2 A$, available at www.jneurosci.org as supplemental material). The means of the fEPSP slope at 60 min of TLQP62 treatment were $260 \pm 11 \%$ (TLQP62 alone), $264 \pm 11 \%$ (TLQP62 + TrkC-Fc), $211 \pm 9 \%$ (TLQP62 + TrkA-Fc), and $106 \pm 8 \%($ TLQP62 + TrkB-Fc) $(n=4 ;$ TLQP62 vs TLQP62 + TrkB-Fc, $p<0.01 ;$ TLQP62 vs TLQP62 + TrkA-Fc and TLQP62 vs TLQP62 + TrkC-Fc, $p>0.05 ;$ ANOVA). In $B$, treatment with the Trk tyrosine kinase inhibitor K252a (100 nм, filled triangles; $200 \mathrm{~nm}$, filled diamonds) blocked TLQP62-induced potentiation, whereas treatment with its analog K252b had significantly less effect (100 nm, open triangles; $200 \mathrm{~nm}$, open diamonds). The means of the fEPSP slope at 60 min of TLQP62 treatment were $260 \pm 11 \%$ (TLQP62 alone), $224 \pm 16 \%$ (TLQP62 + $100 \mathrm{~nm} \mathrm{K252b)}, 194 \pm 12 \%$ (TLQP62 $+200 \mathrm{~nm} \mathrm{K252b)}$, and $101 \pm 2 \%$ (TLQP62 + 100 nм K252a) ( $n=4 ;$ TLQP62 vs TLQP62 + 100 nм K252a, $p<0.01 ;$ TLQP62 vs TLQP62 + 100 nм K252b, $p>$

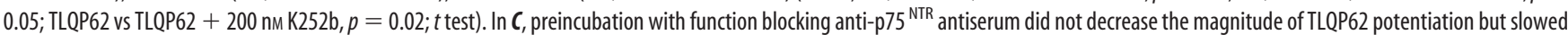
the decline in potentiation after peptide treatment was stopped, whereas normal rabbit serum had no effect (supplemental Fig. $4 B$, available at www.jneurosci.org as supplemental material). The means of the fEPSP slope at 60 and 120 min of TLQP62 treatment were, respectively, $260 \pm 11$ and $101 \pm 10 \%$ (TLQP62 alone) and $264 \pm 10$ and $181 \pm 13 \%$ (TLQP62 + anti-p75 $5^{\text {NTR }}$ ( $n=4$; $p<0.05$ at $120 \mathrm{~min}, t$ test). In $\boldsymbol{D}$, inhibition of tPA activity using tPA STOP (open circles) blocked TLQP62-induced potentiation. The means of the fEPSP slope at 60 min of TLQP62 treatment were $260 \pm 11 \%$ (TLQP62 alone) and $99.5 \pm 12 \%$ (TLQP62 + tPA STOP) $(n=4 ; p<0.01, t$ test). All field EPSP measurements shown are mean \pm SD ( $n=4$ rats per group, 1 slice per rat).

Fig. $2 B$, available at www.jneurosci.org as supplemental material). We further verified that our TrkB-Fc reagent also selectively blocked BDNF-induced hippocampal slice potentiation and latephase LTP induced by tetanic stimulation (supplemental Fig. 3, available at www.jneurosci.org as supplemental material).

Pretreatment of slices with the Trk tyrosine kinase inhibitor K252a before TLQP62 application completely blocked potentiation (100-200 nM) (Fig. 5B) $(p<0.01)$, whereas K252b, a structurally related compound that is a less potent inhibitor of receptor tyrosine kinases, had no significant effect on TLQP62 potentiation at $100 \mathrm{~nm}$ (Fig. $5 B)(p>0.05)$ but completely blocked potentiation at $1 \mu \mathrm{M}$ as did K252a (supplemental Fig. $4 A$, available at www.jneurosci.org as supplemental material). Together with the TrkB-Fc results, this suggested that BDNF signaling via TrkB was required for TLQP62 actions. Also consistent with a mechanism involving BDNF/TrkB signaling, treatment with a function-blocking antibody to the p75 neurotrophin receptor (anti-p75 ${ }^{\text {NTR }}$ ) (Huber and Chao, 1995; Skoff and Adler, 2006) did not block TLQP62-induced potentiation but rather significantly slowed the decay of TLQP62 potentiation after peptide was removed (Fig. 5C) (supplemental Fig. $4 B$, available at www.jneurosci.org as supplemental material $)(p<0.05$ at 120 
min). Because previous studies had suggested that most of the BDNF secreted by hippocampal neurons appears to be in the pro-BDNF precursor form and that tissue plasminogen activator ( $\mathrm{PPA})$ and plasmin are involved in the conversion of pro-BDNF to BDNF (Mowla et al., 1999, 2001; Calabresi et al., 2000; Egan et al., 2003; Chen et al., 2004; Pang and Lu, 2004; Pang et al., 2004), we investigated whether inhibition of tPA catalytic activity affected TLQP62-induced potentiation. We verified that pretreatment of hippocampal slices with the inhibitor tPA STOP blocked late-phase LTP (supplemental Fig. 4C, available at www. jneurosci.org as supplemental material), as shown previously (Baranes et al., 1998). When other slices were similarly pretreated with tPA STOP, TLQP62-induced potentiation was also blocked (Fig. $5 D)(p<0.01)$, suggesting that processing of pro-BDNF to mature BDNF is also a requirement for TLQP62-induced potentiation. Together, these findings suggest that the VGF-derived peptide TLQP62 stimulates secretion of hippocampal proBDNF/BDNF, resulting in synaptic potentiation. Thus, the Vgf gene is not only transcriptionally controlled by BDNF, but the VGF-derived peptide TLQP62 regulates BDNF release and/or availability in the hippocampus.

\section{TLQP62-induced potentiation is neither blocked by the NMDA-type glutamate receptor antagonist APV nor extinguished by previous tetanic stimulation}

To determine whether the TLQP62-mediated synaptic potentiation and LTP share common mechanisms, tetanic stimulation was delivered to slices after TLQP62-induced potentiation reached a plateau. Saturation of LTP by tetanic stimulation did not occlude TLQP62-induced potentiation (Fig. 6A). In addition, saturation of TLQP62 facilitation did not occlude tetanic LTP, suggesting that TLQP62-induced facilitation is mechanistically distinct from LTP (Fig. 6B). Consistent with these findings that TLQP62-induced facilitation and LTP are distinct and previous findings that LTP in hippocampal slices from VGF mutant mice appears normal, pretreatment with the NMDA receptor antagonist AP-5 did not block TLQP62-induced facilitation (Fig. $6 C)(p>0.05)$.

\section{Discussion \\ VGF regulates hippocampal synaptic plasticity through a BDNF-dependent mechanism}

Neurotrophic growth factors play distinct roles in the development and maturation of the nervous system. VGF, originally cloned because it is rapidly regulated by the neurotrophin NGF in PC12 cells (Levi et al., 1985; Cho et al., 1989; Salton et al., 1991), is also induced by BDNF in cortical and hippocampal neurons in vitro (Bonni et al., 1995; Alder et al., 2003) and in vivo (Eagleson et al., 2001). VGF is expressed in the developing and adult hippocampus and amygdala (van den Pol et al., 1994; Lombardo et al., 1995; Snyder and Salton, 1998; Snyder et al., 1998a), consistent with the behavioral role described here. In addition, mRNAs encoding VGF and the BDNF receptor TrkB are extensively coexpressed throughout the CNS in neurons (Snyder et al., 1997), suggesting that VGF could potentially mediate a subset of the behavioral and electrophysiological alterations that are ascribed to BDNF signaling. Moreover, recent studies have demonstrated that the Vgf gene and specific VGF C-terminal peptides play a role in the regulation of depressive behavior (Hunsberger et al., 2007; Thakker-Varia et al., 2007), like BDNF, but the mechanism(s) of action of the VGF protein and its peptides are incompletely understood.

BDNF and its receptor TrkB are critically involved in regulat-

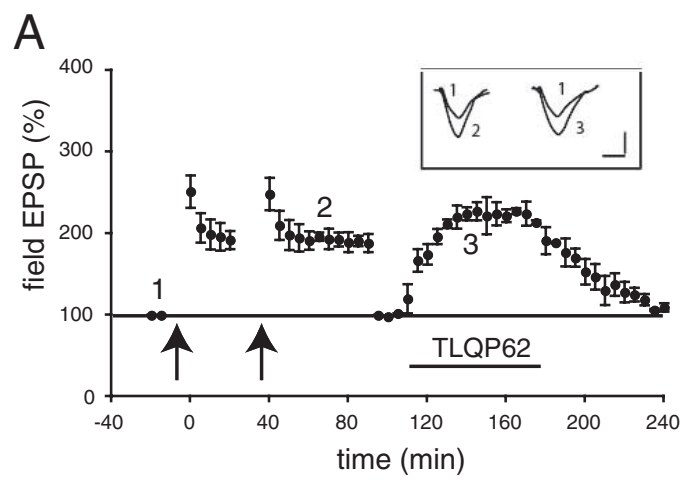

B
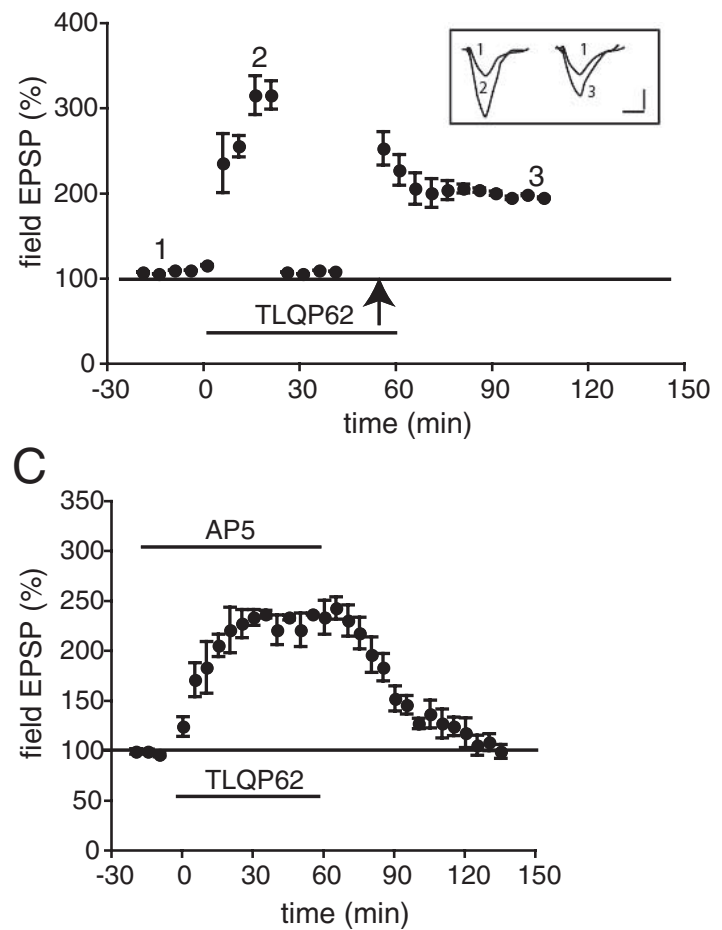

Figure 6. TLQP62-induced potentiation does not involve activation of NMDA-type glutamate receptors, and neither occludes nor is occluded by tetanic stimulation. In $\boldsymbol{A}$, the effect of previous saturating LTP induced by tetanic stimulation (arrows) on subsequent TLQP62induced facilitation of hippocampal synaptic transmission was measured. Application of TLQP62 (10 $\mu \mathrm{M})$ was found to increase fEPSP slope after the induction of stable LTP. The bars indicate duration of TLQP62 treatment. In $\boldsymbol{B}$, after TLQP62-induced potentiation reached a plateau, stimulus intensity was reduced to match the original baseline, and tetanic stimulation (4 trains of $100 \mathrm{~Hz}$; arrow) caused potentiation that was indistinguishable from potentiation in the control condition. In C, hippocampal slices were incubated for 15 min with the NMDA glutamate receptor blocker AP-5 $(50 \mu \mathrm{m})$ and were transferred to the recording chamber and perfused with TLQP62 (10 $\mu \mathrm{m})$ in the presence of AP-5 for $1 \mathrm{~h}$. There was no effect of AP-5 on TLQP62-induced facilitation; the means of the fEPSP slope at $60 \mathrm{~min}$ of TLQP62 treatment were $260 \pm 11 \%$ (TLQP62 alone) and $243 \pm 11 \%$ (TLQP62 + AP-5) $(n=4 ; p>0.05, t$ test). Insets, Representative EPSP traces were recorded at times shown by the numbers on the graphs. Calibration: $10 \mathrm{~ms}, 0.5 \mathrm{mV}$. All field EPSP measurements shown are mean $\pm \mathrm{SD}(n=4$ rats per group, 1 slice per rat).

ing activity-dependant synaptic plasticity. Hippocampal LTP is markedly impaired in TrkB knock-out mice (Minichiello and Klein, 1996; Minichiello et al., 1999, 2002) and in homozygous and heterozygous BDNF knock-out mice, in which it can be rescued by exogenous BDNF (Korte et al., 1995, 1996; Patterson et al., 1996). Application of BDNF to hippocampal slices enhances synaptic transmission (Kang et al., 1997) and increases the probability of LTP induction (Figurov et al., 1996), whereas intrahip- 
pocampal infusion of BDNF triggers LTP in vivo (Messaoudi et al., 1998). BDNF has been found to function presynaptically, regulating glutamate release (Li et al., 1998; Pozzo-Miller et al., 1999; Jovanovic et al., 2000; Tyler and Pozzo-Miller, 2001), and postsynaptically, regulating the phosphorylation and/or expression of NMDA and AMPA glutamate receptors (Black, 1999; Brené et al., 2000; Levine and Kolb, 2000; Kovalchuk et al., 2002). Both presynaptic and postsynaptic components of BDNFinduced plasticity have been described in cultured hippocampal neurons, hippocampal slices, and in vivo (Messaoudi et al., 2002; Zakharenko et al., 2003; Alder et al., 2005). It seems highly likely that BDNF signaling triggers additional pathways, altering expression and/or activity of macromolecules that modulate synaptic plasticity, but few of these downstream gene products have been identified.

Consistent with a functional interaction between BDNF and VGF signaling, the endogenously occurring VGF-derived peptide TLQP62 rapidly induces transient potentiation in hippocampal slices (Fig. 4), isolated from either rats or mice (including comparable potentiation in $V g f^{+/+}, V g f^{+/-}$, and $V g f^{-/-}$genotypes). Potentiation can be blocked by TrkB-Fc but not by other Trk-Fc or Fc reagents, suggesting that TLQP62 induces potentiation in hippocampal slices by modulation of local BDNF release or availability. Inhibition of TLQP62-induced potentiation by the Trk tyrosine kinase inhibitor K252a further supports a mechanism involving BDNF/TrkB signaling. The potency and specificity of K252a and K252b actions with respect to their effects on TLQPinduced potentiation are identical to previous reports of their effects on BDNF-induced slice potentiation (Kang and Schuman, 1995). Application of function-blocking anti-p $75^{\text {NTR }}$ antibody did not affect the magnitude of TLQP-induced potentiation but slowed the decay of potentiation after peptide removal, perhaps by increasing local availability of BDNF/pro-BDNF by blocking BDNF binding to $\mathrm{p} 75^{\mathrm{NTR}}$ or by decreasing $\mathrm{p} 75^{\mathrm{NTR}}$-mediated neurotrophin internalization (Gatzinsky et al., 2001; Santi et al., 2006), although the precise mechanism requires additional investigation. Last, inhibition of tPA activity, which would be expected to block activation of plasmin and conversion of pro-BDNF to BDNF, also blocked TLQP62 induction. Recent data suggest that tPA, plasminogen, and pro-BDNF are extensively copackaged in dense-core secretory granules (Lochner et al., 2008) and colocalize in dendritic spines, in which they undergo activity-dependent and perhaps TLQP62-stimulated release.

Unlike addition of exogenous BDNF, which induces latephase LTP in hippocampal slices that is blocked by TrkB-Fc (Kang et al., 1997; Aicardi et al., 2004), TLQP62-induced potentiation is not long lasting. Could TLQP62 application trigger release of subthreshold amounts of BDNF that may be insufficient to sustain late-phase LTP? Previous studies performed using primary cultures of hippocampal neurons (Balkowiec and Katz, 2002) and hippocampal slices (Aicardi et al., 2004) have demonstrated that the amount of BDNF released is associated with the stimulus strength and the induction of early or late LTP: weaker theta-burst stimulation, which leads only to the initial early phase of LTP (lasting $\sim 35 \mathrm{~min}$ ), is accompanied by brief secretion of small amounts of BDNF, similar to the synaptic potentiation we describe for TLQP62, whereas longer-lasting late-phase LTP induced by stronger stimulation is associated with secretion of more BDNF. Analysis of experiments measuring synaptic activity in primary hippocampal neurons indicates that BDNF-induced plasticity manifests an early component attributed to presynaptic effects and a late postsynaptic, NMDA-receptor-dependent component (Alder et al., 2005). It would seem that this rapid, rela- tively short-lived, early component that is induced by BDNF resembles the plasticity we have characterized in response to TLQP62 treatment.

Our studies therefore indicate (1) that the VGF-derived C-terminal peptide TLQP62 induces synaptic potentiation in hippocampal slices in a BDNF/TrkB-dependent manner, and (2) that VGF mutant mice exhibit a number of abnormalities that are associated with either BDNF deficiency (including deficits in spatial memory and contextual fear memory) (Liu et al., 2004; Heldt et al., 2007) or aberrant pro-BDNF secretion (LTD deficiency) (Rösch et al., 2005; Woo et al., 2005), suggesting that VGF could function in the hippocampus in part by modifying BDNF availability or signaling. Consistent with a role for VGF in regulating synaptic plasticity, treatment of PC12 cells with the VGF-derived C-terminal peptide AQEE30 or infusion of AQEE30 into the rat hippocampal dentate gyrus each induced expression of several gene products that are involved in synaptogenesis, synaptic remodeling, and/or growth factor signaling (including synapsin 1, GRB2, syncam, and EGR2) (Hunsberger et al., 2007). Additional studies are required to further characterize the mechanism(s) of action of VGF C-terminal peptides, determining whether they stimulate electrical potentiation (this study), synaptic activity (Alder et al., 2003), BDNF secretion (this study), proliferation of hippocampal progenitors (Thakker-Varia et al., 2007), and hippocampal gene expression (Hunsberger et al., 2007) by receptordependent signaling pathways.

\section{Shared behavioral deficits in BDNF-deficient and VGF-deficient mice}

Water maze and contextual fear testing suggest that targeted ablation of VGF impairs hippocampal function, deficits that are similar to those reported in BDNF-deficient mice. Cued performances among the three $V g f$ genotypes $(+/+,+/-$, $-/-)$ in the water maze were indistinguishable. Impaired spatial learning and memory with intact cued performance occurs after hippocampal lesion or disconnection in rodents (Olton et al., 1987; Sutherland and Rodriguez, 1989; Packard and McGaugh, 1992; McDonald and White, 1993), indicating that hippocampal activity is required for uncued spatial tasks. Impaired uncued performance in the knock-out animals thus suggests hippocampal dysfunction. This impairment was not caused by general motor, sensory, motivational, or learning deficits, however, because the cued version of the task was learned and performed normally by all groups.

BDNF expression is regulated by learning paradigms including water maze training and fear conditioning (Kesslak et al., 1998; Ma et al., 1998; Hall et al., 2000; Mizuno et al., 2000), and BDNF-deficient heterozygous knock-out mice are severely impaired in contextual fear conditioning (Liu et al., 2004). Mice with altered BDNF or TrkB levels, however, are not consistently impaired in the Morris water maze (Linnarsson et al., 1997; Montkowski and Holsboer, 1997; Minichiello et al., 1999). Similarly, heterozygous VGF mutant mice were not impaired in the water maze but showed an intermediate level of impairment in the contextual fear conditioning task, falling between homozygous VGF knock-out and wild-type mice, suggesting a possible effect of $V g f$ gene dosage on contextual fear memory. Aberrantly regulated BDNF secretion attributable to an SNP-encoded BDNF Val ${ }^{66}$ Met substitution is associated with abnormalities in human memory (Egan et al., 2003) and increased anxiety-like behavior in mice and an attenuated response to antidepressant treatment (Chen et al., 2006). This phenotype has similarities to VGF-deficient mice 
that are depressed in the forced swim and tail suspension tests (Hunsberger et al., 2007) and have abnormal spatial and contextual fear memory (this study).

\section{Association of altered behavior with deficits in LTD or LTP} Altered behavior is often associated with abnormal hippocampal slice physiology but can also be observed in the absence of major disturbances in LTP as we report here for VGF deficiency. For example, dopamine $\beta$ hydroxylase knock-out mice have normal LTP but impaired contextual fear conditioning (Murchison et al., 2004), and NADPH oxidase-deficient mice with mild memory impairments have normal late-phase LTP but do not express high-frequency stimulus-induced early LTP (Kishida et al., 2006). LTD also contributes to hippocampal memory processes (for review, see Kemp and ManahanVaughan, 2007), and performance on spatial memory tasks correlates with the magnitude of hippocampal LTD (Nakao et al., 2002).

Given the potentiating effect of TLQP62, why were no deficiencies detected in early- or late-phase LTP in hippocampal slices from VGF knock-out mice, in contrast to abnormal LTD induction in the paradigm that was tested? Because both $V g f$ knock-out mouse models examined are VGF deficient in the germ line, knock-out mice may be able to compensate for the lack of VGF during development, and thus early- and latephase LTP measured in adult slices appears normal. Because TLQP62 treatment did not induce LTP in hippocampal slices but rather electrical potentiation that could be mechanistically distinguished from LTP (Fig. 6), normal LTP in $V g f^{-} / V g f^{-}$ slices is perhaps not unexpected. Failure to induce LTD in hippocampal slices from VGF knock-out mice could be the result of developmental abnormalities, attributable to germline Vgf ablation, and/or functional loss of VGF and VGFderived peptides in the adult. It should also be noted that only the most common form of LTD, NMDA receptor-dependent LTD, was induced and noted to be abnormal in our studies of VGF knock-out slices; other forms of LTD remain to be tested. Failure to induce LTD in p75 ${ }^{\text {NTR }}$ knock-out mice was previously attributed to decreased pro-BDNF signaling (Woo et al., 2005), but more recently, after pro-BDNF levels were found to be low relative to mature BDNF (Matsumoto et al., 2008), failed LTD in p $75^{\text {NTR }}$ knock-outs was suggested to result from increased spine density and dendritic complexity and altered spine morphology (potentially leading to increased excitatory synaptic transmission and decreased LTD) (Zagrebelsky et al., 2005). Although brain and spinal cord morphology appear grossly normal in VGF knock-out mice (Hahm et al., 1999), it is possible that VGF ablation could result in changes in dendritic structure that were not previously detected, leading to decreased LTD. Alternatively, lack of TLQP62 in the adult could decrease regulated secretion of pro-BDNF, affecting p $75^{\text {NTR }}$ signaling and LTD. This would require that LTD be selectively affected over LTP, perhaps attributable to differences in the sensitivity of the $\mathrm{p} 75^{\mathrm{NTR}}$ and TrkB signaling pathways to secreted pro-BDNF/BDNF or to differences in the relative amounts of locally available pro-BDNF and BDNF.

\section{Modulation of hippocampal plasticity by peptides that regulate feeding and energy expenditure}

In addition to our studies, several other secreted hormones, growth factors, and neuropeptides that regulate energy balance have also been shown to modulate LTP or LTD, including ghrelin (Diano et al., 2006), leptin (Shanley et al., 2001; Har- vey et al., 2005), neuropeptide Y (van den Pol et al., 1996; Whittaker et al., 1999), and even BDNF. This could reflect parallel effects on hypothalamic and hippocampal synaptic plasticity, with coregulation of circuits that control feeding, energy expenditure, and memory (Moran and Gao, 2006). Recent studies demonstrate a role for the C-terminal VGFderived TLQP21 peptide (VGF residues 556-576) in the regulation of metabolism and adiposity (Bartolomucci et al., 2006; Jethwa et al., 2007). Curiously, the phenotype that results from extended intracerebroventricular administration of TLQP21 to mice is very similar to that of VGF knock-out mice, including increased energy expenditure, increased white adipose tissue $\beta 2$-adrenergic receptor mRNA levels, increased white adipose tissue UCP1 mRNA levels, and decreased white adipose tissue weight (Hahm et al., 1999, 2002) (E. Watson and S. Salton, unpublished data). Rather than similar phenotypes, one might anticipate that mice lacking VGF and those chronically treated with the VGF-derived TLQP21 peptide would potentially have opposite metabolic phenotypes. We hypothesized that TLQP21 might function in part by antagonizing specific VGF actions, including those of the $\mathrm{N}$-terminally extended TLQP62 peptide, mimicking VGF deficiency and the phenotype seen in VGF knock-out mice. Consistent with this hypothesis, TLQP21 pretreatment blocked TLQP62-induced electrical potentiation in hippocampal slices (Fig. 4).

Additional experimentation using conditional VGF knockout mice will be required to determine whether decreased VGF expression during hippocampal development is responsible for abnormal behavioral testing in the adult and failure to elicit LTD in hippocampal slices or whether these results reflect a lack of VGF synthesis in the adult hippocampus. Human genetic studies indicate that the $7 \mathrm{q} 22$ region (VGF locus $7 \mathrm{q} 22.1$ ) contains gene(s) that are associated with working memory in schizophrenic families, notably Reelin (Wedenoja et al., 2008). Our behavioral data suggest that polymorphisms in the neighboring $V G F$ gene may need closer scrutiny.

\section{References}

Aicardi G, Argilli E, Cappello S, Santi S, Riccio M, Thoenen H, Canossa M (2004) Induction of long-term potentiation and depression is reflected by corresponding changes in secretion of endogenous brain-derived neurotrophic factor. Proc Natl Acad Sci U S A 101:15788-15792.

Alder J, Thakker-Varia S, Bangasser DA, Kuroiwa M, Plummer MR, Shors TJ, Black IB (2003) Brain-derived neurotrophic factor-induced gene expression reveals novel actions of VGF in hippocampal synaptic plasticity. J Neurosci 23:10800-10808.

Alder J, Thakker-Varia S, Crozier RA, Shaheen A, Plummer MR, Black IB (2005) Early presynaptic and late postsynaptic components contribute independently to brain-derived neurotrophic factor-induced synaptic plasticity. J Neurosci 25:3080-3085.

Balkowiec A, Katz DM (2002) Cellular mechanisms regulating activitydependent release of native brain-derived neurotrophic factor from hippocampal neurons. J Neurosci 22:10399-10407.

Baranes D, Lederfein D, Huang YY, Chen M, Bailey CH, Kandel ER (1998) Tissue plasminogen activator contributes to the late phase of LTP and to synaptic growth in the hippocampal mossy fiber pathway. Neuron 21:813-825.

Bartolomucci A, La Corte G, Possenti R, Locatelli V, Rigamonti AE, Torsello A, Bresciani E, Bulgarelli I, Rizzi R, Pavone F, D’Amato FR, Severini C, Mignogna G, Giorgi A, Schininà ME, Elia G, Brancia C, Ferri GL, Conti R, Ciani B, et al. (2006) TLQP-21, a VGF-derived peptide, increases energy expenditure and prevents the early phase of diet-induced obesity. Proc Natl Acad Sci U S A 103:14584-14589.

Black IB (1999) Trophic regulation of synaptic plasticity. J Neurobiol 41:108-118.

Bonni A, Ginty DD, Dudek H, Greenberg ME (1995) Serine 133- 
phosphorylated CREB induces transcription via a cooperative mechanism that may confer specificity to neurotrophin signals. Mol Cell Neurosci 6:168-183.

Bozdagi O, Shan W, Tanaka H, Benson DL, Huntley GW (2000) Increasing numbers of synaptic puncta during late-phase LTP: N-cadherin is synthesized, recruited to synaptic sites, and required for potentiation. Neuron 28:245-259.

Brené S, Messer C, Okado H, Hartley M, Heinemann SF, Nestler EJ (2000) Regulation of GluR2 promoter activity by neurotrophic factors via a neuron-restrictive silencer element. Eur J Neurosci 12:1525-1533.

Brun VH, Ytterbo K, Morris RG, Moser MB, Moser EI (2001) Retrograde amnesia for spatial memory induced by NMDA receptor-mediated longterm potentiation. J Neurosci 21:356-362.

Bunsey M, Eichenbaum H (1996) Conservation of hippocampal memory function in rats and humans. Nature 379:255-257.

Calabresi P, Napolitano M, Centonze D, Marfia GA, Gubellini P, Teule MA, Berretta N, Bernardi G, Frati L, Tolu M, Gulino A (2000) Tissue plasminogen activator controls multiple forms of synaptic plasticity and memory. Eur J Neurosci 12:1002-1012.

Chen ZY, Patel PD, Sant G, Meng CX, Teng KK, Hempstead BL, Lee FS (2004) Variant brain-derived neurotrophic factor (BDNF) (Met66) alters the intracellular trafficking and activity-dependent secretion of wildtype BDNF in neurosecretory cells and cortical neurons. J Neurosci 24:4401-4411.

Chen ZY, Jing D, Bath KG, Ieraci A, Khan T, Siao CJ, Herrera DG, Toth M, Yang C, McEwen BS, Hempstead BL, Lee FS (2006) Genetic variant BDNF (Val66Met) polymorphism alters anxiety-related behavior. Science 314:140-143.

Cho KO, Skarnes WC, Minsk B, Palmieri S, Jackson-Grusby L, Wagner JA (1989) Nerve growth factor regulates gene expression by several distinct mechanisms. Mol Cell Biol 9:135-143.

Davies CH, Davies SN, Collingridge GL (1990) Paired-pulse depression of monosynaptic GABA-mediated inhibitory postsynaptic responses in rat hippocampus. J Physiol 424:513-531.

Diano S, Farr SA, Benoit SC, McNay EC, da Silva I, Horvath B, Gaskin FS, Nonaka N, Jaeger LB, Banks WA, Morley JE, Pinto S, Sherwin RS, Xu L, Yamada KA, Sleeman MW, Tschöp MH, Horvath TL (2006) Ghrelin controls hippocampal spine synapse density and memory performance. Nat Neurosci 9:381-388.

Duman RS (2005) Neurotrophic factors and regulation of mood: role of exercise, diet and metabolism. Neurobiol Aging 26 [Suppl 1]:88-93.

Eagleson KL, Fairfull LD, Salton SR, Levitt P (2001) Regional differences in neurotrophin availability regulate selective expression of VGF in the developing limbic cortex. J Neurosci 21:9315-9324.

Egan MF, Kojima M, Callicott JH, Goldberg TE, Kolachana BS, Bertolino A, Zaitsev E, Gold B, Goldman D, Dean M, Lu B, Weinberger DR (2003) The BDNF val66met polymorphism affects activity-dependent secretion of BDNF and human memory and hippocampal function. Cell 112:257-269.

Farmer J, Zhao X, van Praag H, Wodtke K, Gage FH, Christie BR (2004) Effects of voluntary exercise on synaptic plasticity and gene expression in the dentate gyrus of adult male Sprague-Dawley rats in vivo. Neuroscience 124:71-79.

Figurov A, Pozzo-Miller LD, Olafsson P, Wang T, Lu B (1996) Regulation of synaptic responses to high-frequency stimulation and LTP by neurotrophins in the hippocampus. Nature 381:706-709.

Gatzinsky KP, Haugland RP, Thrasivoulou C, Orike N, Budi-Santoso AW, Cowen T (2001) p75 and TrkA receptors are both required for uptake of NGF in adult sympathetic neurons: use of a novel fluorescent NGF conjugate. Brain Res 920:226-238.

Goosens KA, Maren S (2001) Contextual and auditory fear conditioning are mediated by the lateral, basal, and central amygdaloid nuclei in rats. Learn Mem 8:148-155.

Gorski JA, Balogh SA, Wehner JM, Jones KR (2003) Learning deficits in forebrain-restricted brain-derived neurotrophic factor mutant mice. Neuroscience 121:341-354.

Hahm S, Mizuno TM, Wu TJ, Wisor JP, Priest CA, Kozak CA, Boozer CN, Peng B, McEvoy RC, Good P, Kelley KA, Takahashi JS, Pintar JE, Roberts JL, Mobbs CV, Salton SR (1999) Targeted deletion of the Vgf gene indicates that the encoded secretory peptide precursor plays a novel role in the regulation of energy balance. Neuron 23:537-548.

Hahm S, Fekete C, Mizuno TM, Windsor J, Yan H, Boozer CN, Lee C,
Elmquist JK, Lechan RM, Mobbs CV, Salton SR (2002) VGF is required for obesity induced by diet, gold thioglucose treatment and agouti, and is differentially regulated in POMC- and NPY-containing arcuate neurons in response to fasting. J Neurosci 22:6929-6938.

Hall J, Thomas KL, Everitt BJ (2000) Rapid and selective induction of BDNF expression in the hippocampus during contextual learning. Nat Neurosci 3:533-535.

Harvey J, Shanley LJ, O’Malley D, Irving AJ (2005) Leptin: a potential cognitive enhancer? Biochem Soc Trans 33:1029-1032.

Heldt SA, Stanek L, Chhatwal JP, Ressler KJ (2007) Hippocampus-specific deletion of BDNF in adult mice impairs spatial memory and extinction of aversive memories. Mol Psychiatry 12:656-670.

Huber LJ, Chao MV (1995) Mesenchymal and neuronal cell expression of the p75 neurotrophin receptor gene occur by different mechanisms. Dev Biol 167:227-238.

Hunsberger JG, Newton SS, Bennett AH, Duman CH, Russell DS, Salton SR, Duman RS (2007) Antidepressant actions of the exercise-regulated gene VGF. Nat Med 13:1476-1482.

Jethwa PH, Warner A, Nilaweera KN, Brameld JM, Keyte JW, Carter WG, Bolton N, Bruggraber M, Morgan PJ, Barrett P, Ebling FJ (2007) VGFderived peptide, TLQP-21, regulates food intake and body weight in Siberian hamsters. Endocrinology 148:4044-4055.

Jovanovic JN, Czernik AJ, Fienberg AA, Greengard P, Sihra TS (2000) Synapsins as mediators of BDNF-enhanced neurotransmitter release. Nat Neurosci 3:323-329.

Kang H, Schuman EM (1995) Long-lasting neurotrophin-induced enhancement of synaptic transmission in the adult hippocampus. Science 267:1658-1662.

Kang H, Welcher AA, Shelton D, Schuman EM (1997) Neurotrophins and time: different roles for TrkB signaling in hippocampal long-term potentiation. Neuron 19:653-664.

Karege F, Vaudan G, Schwald M, Perroud N, La Harpe R (2005) Neurotrophin levels in postmortem brains of suicide victims and the effects of antemortem diagnosis and psychotropic drugs. Brain Res Mol Brain Res 136:29-37.

Kemp A, Manahan-Vaughan D (2007) Hippocampal long-term depression: master or minion in declarative memory processes? Trends Neurosci 30:111-118.

Kesslak JP, So V, Choi J, Cotman CW, Gomez-Pinilla F (1998) Learning upregulates brain-derived neurotrophic factor messenger ribonucleic acid: a mechanism to facilitate encoding and circuit maintenance? Behav Neurosci 112:1012-1019.

Kishida KT, Hoeffer CA, Hu D, Pao M, Holland SM, Klann E (2006) Synaptic plasticity deficits and mild memory impairments in mouse models of chronic granulomatous disease. Mol Cell Biol 26:5908-5920.

Korte M, Carroll P, Wolf E, Brem G, Thoenen H, Bonhoeffer T (1995) Hippocampal long-term potentiation is impaired in mice lacking brainderived neurotrophic factor. Proc Natl Acad Sci U S A 92:8856-8860.

Korte M, Griesbeck O, Gravel C, Carroll P, Staiger V, Thoenen H, Bonhoeffer $\mathrm{T}$ (1996) Virus-mediated gene transfer into hippocampal CA1 region restores long-term potentiation in brain-derived neurotrophic factor mutant mice. Proc Natl Acad Sci U S A 93:12547-12552.

Kovalchuk Y, Hanse E, Kafitz KW, Konnerth A (2002) Postsynaptic induction of BDNF-mediated long-term potentiation. Science 295:1729-1734.

Levi A, Eldridge JD, Paterson BM (1985) Molecular cloning of a gene sequence regulated by nerve growth factor. Science 229:393-395.

Levine ES, Kolb JE (2000) Brain-derived neurotrophic factor increases activity of NR2B-containing $N$-methyl-D-aspartate receptors in excised patches from hippocampal neurons. J Neurosci Res 62:357-362.

Li YX, Zhang Y, Lester HA, Schuman EM, Davidson N (1998) Enhancement of neurotransmitter release induced by brain-derived neurotrophic factor in cultured hippocampal neurons. J Neurosci 18:10231-10240.

Linnarsson S, Björklund A, Ernfors P (1997) Learning deficit in BDNF mutant mice. Eur J Neurosci 9:2581-2587.

Liu IY, Lyons WE, Mamounas LA, Thompson RF (2004) Brain-derived neurotrophic factor plays a critical role in contextual fear conditioning. J Neurosci 24:7958-7963.

Lochner JE, Spangler E, Chavarha M, Jacobs C, McAllister K, Schuttner LC, Scalettar BA (2008) Efficient copackaging and cotransport yields postsynaptic colocalization of neuromodulators associated with synaptic plasticity. Dev Neurobiol 68:1243-1256.

Lombardo A, Rabacchi SA, Cremisi F, Pizzorusso T, Cenni MC, Possenti R, 
Barsacchi G, Maffei L (1995) A developmentally regulated nerve growth factor-induced gene, VGF, is expressed in geniculocortical afferents during synaptogenesis. Neuroscience 65:997-1008.

Ma YL, Wang HL, Wu HC, Wei CL, Lee EH (1998) Brain-derived neurotrophic factor antisense oligonucleotide impairs memory retention and inhibits long-term potentiation in rats. Neuroscience 82:957-967.

Matsumoto T, Rauskolb S, Polack M, Klose J, Kolbeck R, Korte M, Barde YA (2008) Biosynthesis and processing of endogenous BDNF: CNS neurons store and secrete BDNF, not pro-BDNF. Nat Neurosci 11:131-133.

McDonald RJ, White NM (1993) A triple dissociation of memory systems: hippocampus, amygdala, and dorsal striatum. Behav Neurosci 107:3-22.

Messaoudi E, Bârdsen K, Srebro B, Bramham CR (1998) Acute intrahippocampal infusion of BDNF induces lasting potentiation of synaptic transmission in the rat dentate gyrus. J Neurophysiol 79:496-499.

Messaoudi E, Ying SW, Kanhema T, Croll SD, Bramham CR (2002) Brainderived neurotrophic factor triggers transcription-dependent, late phase long-term potentiation in vivo. J Neurosci 22:7453-7461.

Minichiello L, Klein R (1996) TrkB and TrkC neurotrophin receptors cooperate in promoting survival of hippocampal and cerebellar granule neurons. Genes Dev 10:2849-2858.

Minichiello L, Korte M, Wolfer D, Kühn R, Unsicker K, Cestari V, RossiArnaud C, Lipp HP, Bonhoeffer T, Klein R (1999) Essential role for TrkB receptors in hippocampus-mediated learning. Neuron 24:401-414.

Minichiello L, Calella AM, Medina DL, Bonhoeffer T, Klein R, Korte M (2002) Mechanism of TrkB-mediated hippocampal long-term potentiation. Neuron 36:121-137.

Mizuno M, Yamada K, Olariu A, Nawa H, Nabeshima T (2000) Involvement of brain-derived neurotrophic factor in spatial memory formation and maintenance in a radial arm maze test in rats. J Neurosci 20:7116-7121.

Monteggia LM, Barrot M, Powell CM, Berton O, Galanis V, Gemelli T, Meuth S, Nagy A, Greene RW, Nestler EJ (2004) Essential role of brain-derived neurotrophic factor in adult hippocampal function. Proc Natl Acad Sci U S A 101:10827-10832.

Montkowski A, Holsboer F (1997) Intact spatial learning and memory in transgenic mice with reduced BDNF. Neuroreport 8:779-782.

Moran TH, Gao S (2006) Looking for food in all the right places? Cell Metab 3:233-234.

Mowla SJ, Pareek S, Farhadi HF, Petrecca K, Fawcett JP, Seidah NG, Morris SJ, Sossin WS, Murphy RA (1999) Differential sorting of nerve growth factor and brain-derived neurotrophic factor in hippocampal neurons. J Neurosci 19:2069-2080.

Mowla SJ, Farhadi HF, Pareek S, Atwal JK, Morris SJ, Seidah NG, Murphy RA (2001) Biosynthesis and post-translational processing of the precursor to brain-derived neurotrophic factor. J Biol Chem 276:12660-12666.

Murchison CF, Zhang XY, Zhang WP, Ouyang M, Lee A, Thomas SA (2004) A distinct role for norepinephrine in memory retrieval. Cell 117:131-143.

Nakao K, Ikegaya Y, Yamada MK, Nishiyama N, Matsuki N (2002) Hippocampal long-term depression as an index of spatial working memory. Eur J Neurosci 16:970-974.

Newton SS, Collier EF, Hunsberger J, Adams D, Terwilliger R, Selvanayagam E, Duman RS (2003) Gene profile of electroconvulsive seizures: induction of neurotrophic and angiogenic factors. J Neurosci 23:10841-10851.

Olton DS, Meck WH, Church RM (1987) Separation of hippocampal and amygdaloid involvement in temporal memory dysfunctions. Brain Res 404:180-188

Packard MG, McGaugh JL (1992) Double dissociation of fornix and caudate nucleus lesions on acquisition of two water maze tasks: further evidence for multiple memory systems. Behav Neurosci 106:439-446.

Pang PT, Lu B (2004) Regulation of late-phase LTP and long-term memory in normal and aging hippocampus: role of secreted proteins tPA and BDNF. Ageing Res Rev 3:407-430.

Pang PT, Teng HK, Zaitsev E, Woo NT, Sakata K, Zhen S, Teng KK, Yung WH, Hempstead BL, Lu B (2004) Cleavage of proBDNF by tPA/plasmin is essential for long-term hippocampal plasticity. Science 306:487-491.

Patterson SL, Abel T, Deuel TA, Martin KC, Rose JC, Kandel ER (1996) Recombinant BDNF rescues deficits in basal synaptic transmission and hippocampal LTP in BDNF knockout mice. Neuron 16:1137-1145.

Phillips RG, LeDoux JE (1992) Differential contribution of amygdala and hippocampus to cued and contextual fear conditioning. Behav Neurosci 106:274-285.
Poo MM (2001) Neurotrophins as synaptic modulators. Nat Rev Neurosci 2:24-32.

Pozzo-Miller LD, Gottschalk W, Zhang L, McDermott K, Du J, Gopalakrishnan R, Oho C, Sheng ZH, Lu B (1999) Impairments in high-frequency transmission, synaptic vesicle docking, and synaptic protein distribution in the hippocampus of BDNF knock-out mice. J Neurosci 19:4972-4983.

Rösch H, Schweigreiter R, Bonhoeffer T, Barde YA, Korte M (2005) The neurotrophin receptor p75NTR modulates long-term depression and regulates the expression of AMPA receptor subunits in the hippocampus. Proc Natl Acad Sci U S A 102:7362-7367.

Saarelainen T, Hendolin P, Lucas G, Koponen E, Sairanen M, MacDonald E, Agerman K, Haapasalo A, Nawa H, Aloyz R, Ernfors P, Castrén E (2003) Activation of the TrkB neurotrophin receptor is induced by antidepressant drugs and is required for antidepressant-induced behavioral effects. J Neurosci 23:349-357.

Salton SR, Fischberg DJ, Dong KW (1991) Structure of the gene encoding VGF, a nervous system-specific mRNA that is rapidly and selectively induced by nerve growth factor in PC12 cells. Mol Cell Biol 11:2335-2349.

Santi S, Cappello S, Riccio M, Bergami M, Aicardi G, Schenk U, Matteoli M, Canossa M (2006) Hippocampal neurons recycle BDNF for activitydependent secretion and LTP maintenance. EMBO J 25:4372-4380.

Shanley LJ, Irving AJ, Harvey J (2001) Leptin enhances NMDA receptor function and modulates hippocampal synaptic plasticity. J Neurosci 21:RC186(1-6).

Shimizu E, Hashimoto K, Okamura N, Koike K, Komatsu N, Kumakiri C, Nakazato M, Watanabe H, Shinoda N, Okada S, Iyo M (2003) Alterations of serum levels of brain-derived neurotrophic factor (BDNF) in depressed patients with or without antidepressants. Biol Psychiatry 54:70-75

Shirayama Y, Chen AC, Nakagawa S, Russell DS, Duman RS (2002) Brainderived neurotrophic factor produces antidepressant effects in behavioral models of depression. J Neurosci 22:3251-3261.

Siuciak JA, Lewis DR, Wiegand SJ, Lindsay RM (1997) Antidepressant-like effect of brain-derived neurotrophic factor (BDNF). Pharmacol Biochem Behav 56:131-137.

Skoff AM, Adler JE (2006) Nerve growth factor regulates substance P in adult sensory neurons through both TrkA and p75 receptors. Exp Neurol 197:430-436

Snyder SE, Salton SR (1998) Expression of VGF mRNA in the adult rat central nervous system. J Comp Neurol 394:91-105.

Snyder SE, Li J, Salton SR (1997) Comparison of VGF and trk mRNA distributions in the developing and adult rat nervous systems. Brain Res Mol Brain Res 49:307-311.

Snyder SE, Pintar JE, Salton SR (1998a) Developmental expression of VGF mRNA in the prenatal and postnatal rat. J Comp Neurol 394:64-90.

Snyder SE, Cheng HW, Murray KD, Isackson PJ, McNeill TH, Salton SR (1998b) The messenger RNA encoding VGF, a neuronal peptide precursor, is rapidly regulated in the rat central nervous system by neuronal activity, seizure and lesion. Neuroscience 82:7-19.

Strauss J, Barr CL, George CJ, Devlin B, Vetró A, Kiss E, Baji I, King N, Shaikh S, Lanktree M, Kovacs M, Kennedy JL (2005) Brain-derived neurotrophic factor variants are associated with childhood-onset mood disorder: confirmation in a Hungarian sample. Mol Psychiatry 10:861-867.

Sutherland RJ, Rodriguez AJ (1989) The role of the fornix/fimbria and some related subcortical structures in place learning and memory. Behav Brain Res 32:265-277.

Thakker-Varia S, Krol JJ, Nettleton J, Bilimoria PM, Bangasser DA, Shors TJ, Black IB, Alder J (2007) The neuropeptide VGF produces antidepressant-like behavioral effects and enhances proliferation in the hippocampus. J Neurosci 27:12156-12167.

Tyler WJ, Pozzo-Miller LD (2001) BDNF enhances quantal neurotransmitter release and increases the number of docked vesicles at the active zones of hippocampal excitatory synapses. J Neurosci 21:4249-4258.

Valenzuela DM, Murphy AJ, Frendewey D, Gale NW, Economides AN, Auerbach W, Poueymirou WT, Adams NC, Rojas J, Yasenchak J, Chernomorsky R, Boucher M, Elsasser AL, Esau L, Zheng J, Griffiths JA, Wang X, Su H, Xue Y, Dominguez MG, et al. (2003) High-throughput engineering of the mouse genome coupled with high-resolution expression analysis. Nat Biotechnol 21:652-659.

van den Pol AN, Bina K, Decavel C, Ghosh P (1994) VGF expression in the brain. J Comp Neurol 347:455-469.

van den Pol AN, Obrietan K, Chen G, Belousov AB (1996) Neuropeptide 
Y-mediated long-term depression of excitatory activity in suprachiasmatic nucleus neurons. J Neurosci 16:5883-5895.

Watson E, Hahm S, Mizuno TM, Windsor J, Montgomery C, Scherer PE, Mobbs CV, Salton SR (2005) VGF ablation blocks the development of hyperinsulinemia and hyperglycemia in several mouse models of obesity. Endocrinology 146:5151-5163.

Wedenoja J, Loukola A, Tuulio-Henriksson A, Paunio T, Ekelund J, Silander K, Varilo T, Heikkilä K, Suvisaari J, Partonen T, Lönnqvist J, Peltonen L (2008) Replication of linkage on chromosome 7q22 and association of the regional Reelin gene with working memory in schizophrenia families. Mol Psychiatry 13:673-684.

Whittaker E, Vereker E, Lynch MA (1999) Neuropeptide Y inhibits gluta- mate release and long-term potentiation in rat dentate gyrus. Brain Res 827:229-233.

Woo NH, Teng HK, Siao CJ, Chiaruttini C, Pang PT, Milner TA, Hempstead BL, Lu B (2005) Activation of p75NTR by proBDNF facilitates hippocampal long-term depression. Nat Neurosci 8:1069-1077.

Zagrebelsky M, Holz A, Dechant G, Barde YA, Bonhoeffer T, Korte M (2005) The p75 neurotrophin receptor negatively modulates dendrite complexity and spine density in hippocampal neurons. J Neurosci 25:9989-9999.

Zakharenko SS, Patterson SL, Dragatsis I, Zeitlin SO, Siegelbaum SA, Kandel ER, Morozov A (2003) Presynaptic BDNF required for a presynaptic but not postsynaptic component of LTP at hippocampal CA1-CA3 synapses. Neuron 39:975-990. 